\title{
The Globular C1q Receptor Is Required for Epidermal Growth Factor Receptor Signaling during Candida albicans Infection
}

\author{
Quynh T. Phan, ${ }^{\text {a }}$ (D) Jianfeng Lin, ${ }^{a}$ Norma V. Solis, ${ }^{a}$ Michael Eng, ${ }^{a}$ (D) Marc Swidergall, ${ }^{\text {a,b }}$ Feng Wang, ${ }^{c}$ Shan Li, ${ }^{c}$ Sarah L. Gaffen, ${ }^{d}$ \\ Tsui-Fen Chou, ${ }^{c *}$ (D) Scott G. Filler ${ }^{a, b}$
}

\author{
alnstitute for Infection and Immunity, Lundquist Institute for Biomedical Innovation at Harbor-UCLA Medical Center, Torrance, California, USA \\ bDavid Geffen School of Medicine at UCLA, Los Angeles, California, USA \\ cDepartment of Pediatrics, Lundquist Institute for Biomedical Innovation at Harbor-UCLA Medical Center, Torrance, California, USA \\ dDivision of Rheumatology and Clinical Immunology, University of Pittsburgh, Pittsburgh, Pennsylvania, USA
}

ABSTRACT During oropharyngeal candidiasis, Candida albicans activates the epidermal growth factor receptor (EGFR), which induces oral epithelial cells to endocytose the fungus and synthesize proinflammatory mediators. To elucidate EGFR signaling pathways that are stimulated by $C$. albicans, we used proteomics to identify 1,214 proteins that were associated with EGFR in C. albicans-infected cells. Seven of these proteins were selected for additional study. Among these proteins, WW domain-binding protein 2, Toll-interacting protein, interferon-induced transmembrane protein 3 (IFITM3), and the globular C1q receptor (gC1qR) were found to associate with EGFR in viable oral epithelial cells. Each of these proteins was required for maximal endocytosis of $C$. albicans, and all regulated fungusinduced production of interleukin-1 $\beta$ (IL-1 $\beta$ ) and/or IL-8, either positively or negatively. $\mathrm{gC1qR}$ was found to function as a key coreceptor with EGFR. Interacting with the C. albicans Als3 invasin, gC1qR was required for the fungus to induce autophosphorylation of both EGFR and the ephrin type A receptor 2. The combination of $\mathrm{gC1qR}$ and EGFR was necessary for maximal endocytosis of $C$. albicans and secretion of IL- $1 \beta, \mathrm{IL}-8$, and granulocyte-macrophage colony-stimulating factor (GM-CSF) by human oral epithelial cells. In mouse oral epithelial cells, inhibition of gC1qR failed to block C. albicans-induced phosphorylation, and knockdown of IFITM3 did not inhibit $C$. albicans endocytosis, indicating that $\mathrm{gC1qR}$ and IFITM3 function differently in mouse versus human oral epithelial cells. Thus, this work provides an atlas of proteins that associate with EGFR and identifies several that play a central role in the response of human oral epithelial cells to $C$. albicans infection.

IMPORTANCE Oral epithelial cells play a key role in the pathogenesis of oropharyngeal candidiasis. In addition to being target host cells for $C$. albicans adherence and invasion, they secrete proinflammatory cytokines and chemokines that recruit $\mathrm{T}$ cells and activated phagocytes to foci of infection. It is known that C. albicans activates EGFR on oral epithelial cells, which induces these cells to endocytose the organism and stimulates them to secrete proinflammatory mediators. To elucidate the EGFR signaling pathways that govern these responses, we analyzed the epithelial cell proteins that associate with EGFR in C. albicans-infected epithelial cells. We identified four proteins that physically associate with EGFR and that regulate different aspects of the epithelial response to $C$. albicans. One of these is $\mathrm{gC} 1 \mathrm{qR}$, which is required for C. albicans to activate EGFR, induce endocytosis, and stimulate the secretion of proinflammatory mediators, indicating that $\mathrm{gC} 1 \mathrm{qR}$ functions as a key coreceptor with EGFR.

KEYWORDS Candida albicans, oral epithelial cells, endocytosis, epidermal growth factor receptor, host defense
Citation Phan QT, Lin J, Solis NV, Eng M, Swidergall M, Wang F, Li S, Gaffen SL, Chou T-F, Filler SG. 2021. The globular C1q receptor is required for epidermal growth factor receptor signaling during Candida albicans infection. mBio 12:e2716-21. https://doi.org/10.1128/ mBio.02716-21.

Editor J. Andrew Alspaugh, Duke University Medical Center

Copyright $\odot 2021$ Phan et al. This is an openaccess article distributed under the terms of the Creative Commons Attribution 4.0 International license.

Address correspondence to Scott G. Filler, sfiller@ucla.edu.

*Present address: Tsui-Fen Chou, Division of Biology and Biological Engineering, California Institute of Technology, Pasadena, California, USA.

Received 11 September 2021

Accepted 21 September 2021

Published 2 November 2021 
andida albicans grows as a harmless commensal in the oral cavity of at least $50 \%$ of normal adults (1). However, when either local or systemic immune defenses are weakened, C. albicans can proliferate and cause oropharyngeal candidiasis (2). This disease causes substantial morbidity in patients with HIV/AIDS, dentures, organ transplantation, cancer, diabetes, and xerostomia (3-6). Although most patients with oropharyngeal candidiasis readily respond to treatment with antifungal agents such as fluconazole during their first episode of infection, patients with recurrent disease are at risk for developing infection with an azole-resistant strain $(7,8)$.

During oropharyngeal candidiasis, $C$. albicans invades the epithelial cell lining of the oropharynx, stimulating a strong proinflammatory host response that is driven by interleukin-17 (IL-17) and IL-22 signaling, which is initiated from innate lymphocytes and subsequently from the adaptive immune response $(9,10)$. When $C$. albicans adheres to an epithelial cell, it interacts with and activates multiple epithelial cell receptors, including the ephrin type $A$ receptor 2 (EphA2), E-cadherin, the plateletderived growth factor receptor BB, HER2, and the epidermal growth factor receptor (EGFR) (11-13). Among these receptors, EGFR plays a central role in triggering the epithelial cell endocytosis of $C$. albicans and stimulating a proinflammatory response. EGFR interacts with EphA2, HER2, E-cadherin, Src family kinases, and the aryl hydrocarbon receptor, triggering changes in the actin cytoskeleton that lead to the endocytosis of the fungus $(11,13,14)$. EGFR also interacts with EphA2 to stimulate epithelial cells to secrete proinflammatory mediators, including defensins, IL- $1 \alpha, \mathrm{IL}-1 \beta, \mathrm{CXCL} 8 / \mathrm{IL}-8$, and $\operatorname{CCL} 20(11,15,16)$. The defensins have direct candidacidal activity, while the cytokines and chemokines recruit phagocytes to the focus of infection and enhance their capacity to kill the invading fungus.

Because of the key role of EGFR in mediating the oral epithelial cell response to $C$. albicans, we sought to obtain a more comprehensive view of the spectrum of host cell proteins that interact with this receptor. Using a proteomics approach, we found that EGFR associates with 1,214 epithelial cell proteins in C. albicans-infected cells. Of these proteins, 13 had increased association with EGFR in the $C$. albicans-infected cells relative to uninfected cells. In intact epithelial cells, four proteins associated with EGFR in the vicinity of $C$. albicans hyphae: WW domain-binding protein 2 (WBP2), which governs EGFR expression and signaling in cancer cells; Toll-interacting protein (TOLLIIP), which is a negative regulator of Toll-like receptor signaling; interferon-induced transmembrane protein 3 (IFITM3), which is an antiviral protein; and the globular $\mathrm{C} 1 \mathrm{q}$ receptor ( $\mathrm{gC} 1 \mathrm{qR})$, which is a multifunctional protein that interacts with a variety of serum components. We interrogated these proteins in the context of C. albicans infection of human oral epithelial cells, and found that each of these proteins is required for maximal endocytosis of $C$. albicans. Moreover, they all regulate the production of innate cytokines, such as IL-1 $\beta$ and/or IL-8, either positively or negatively. Additionally, $\mathrm{gC1qR}$ functions as a key coreceptor that is required for $C$. albicans to stimulate EGFR and to induce endocytosis and an epithelial cell proinflammatory response.

\section{RESULTS}

EGFR associates with multiple proteins that mediate endocytosis and govern actin dynamics. To identify epithelial cell proteins that associate with EGFR, we infected the OKF6/TERT-2 oral epithelial cell line (17) with C. albicans yeast for 90 min, cross-linked the proteins with formaldehyde, and then performed immunoprecipitation of whole-cell lysates with an anti-EGFR antibody. The proteins that were associated with EGFR were then identified by liquid chromatography-tandem mass spectrometry (LC-MS/MS). As controls, we processed in parallel uninfected epithelial cells as well as epithelial cells incubated with epidermal growth factor (EGF) for $5 \mathrm{~min}$. In total, 1,214 proteins were associated with EGFR in all three samples of epithelial cells infected with C. albicans (see Table S1 in the supplemental material), and 1,278 were associated with EGFR in both samples of epithelial cells that had been incubated with EGF (see Table S2 in the supplemental material). The majority of these proteins were constitutively associated with EGFR. However, 13 proteins showed at least a 2-fold increase in association with EGFR in all three samples of $C$. albicans-infected cells relative to uninfected cells (Table 1), and 37 had increased association with EGFR in the EGF-exposed cells (see 
TABLE 1 List of proteins that had increased association with EGFR in response to infection with C. albicans

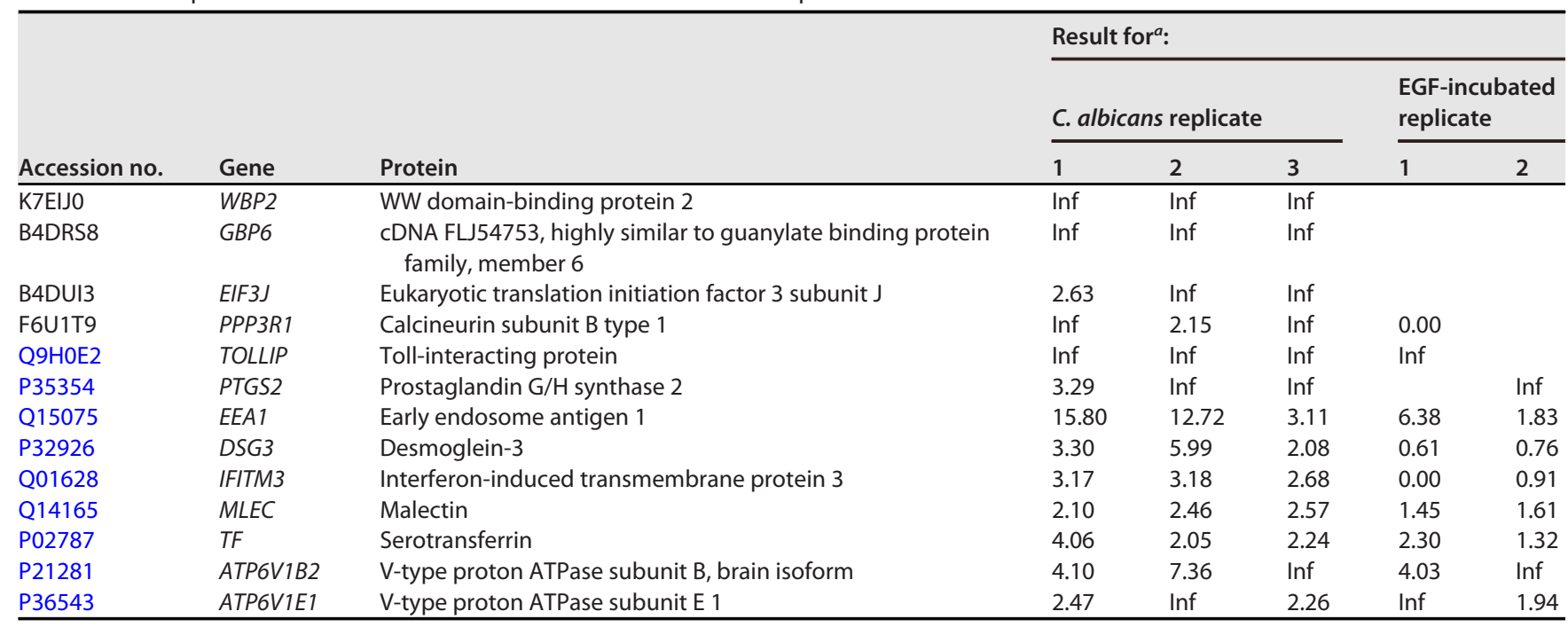

aShown are individual results from 3 biological replicates for epithelial cells infected with C. albicans for $90 \mathrm{~min}$ and 2 biological replicates from epithelial cells incubated with epidermal growth factor (EGF) for $5 \mathrm{~min}$. Values are the ratio of the amount of protein detected in cells exposed to C. albicans or EGF relative to unstimulated control cells. "Inf" (i.e., infinite change") indicates proteins that were undetectable in unstimulated control cells.

Table S3 in the supplemental material). Among the proteins that had increased association with EGFR in response to C. albicans infection, four associated with EGFR only in cells exposed to C. albicans, but not EGF. Among these were WW domain-binding protein 2 (WBP2), guanylate binding protein family member 6 (GPB6), subunit $J$ of eukaryotic translation initiation factor 3 , and calcineurin subunit B type 1 (Table 1). Only three proteins were found to associate with EGFR in cells exposed to EGF but not $C$. albicans. One was EGF itself, and the others were galectin-9B and ERBB receptor feedback inhibitor 1 (Table S3). Collectively, these results suggest that while the profiles of proteins that associate with EGFR in response to C. albicans and EGF are similar, some proteins are uniquely recruited in response to $C$. albicans.

Analysis of proteins constitutively associated with EGFR provided insight into the mechanisms by which EGFR induces epithelial cells to endocytose $C$. albicans. We found that EGFR associated with EphA2, E-cadherin, and HER2 (Table 2), consistent with our previous findings that EGFR functions in the same pathways as these three receptors $(11,13,18)$. EGFR was found to associate with two members of the Src family of kinases, Lyn and Yes, suggesting that these kinases may activate EGFR (Table 2) (14). It was notable that EGFR was associated with the lipid raft proteins caveolin-1, caveolin-2, flotillin-1, flotillin-2, arf6, and RhoA (Table 2) $(19,20)$, indicating that EGFR-containing complexes are likely localized to these microdomains.

The endocytosis of $C$. albicans is mediated in part by the clathrin and cortactin internalization pathway (21). Consistent with this mechanism, the clathrin heavy and light chains, cortactin, and the phosphatidylinositol-binding clathrin assembly protein were found to associate with EGFR (Table 2). Activation of the clathrin pathway induces rearrangement of actin filaments, leading to the formation of pseudopods that engulf the fungus, leading to the formation of an endocytic vacuole (22). We found that EGFR associated with all seven members of the actin-related protein 2/3 (arp2/3) complex, including actin-related proteins 2 and 3 and actin-related protein complex subunits 1B, 2, 3, 4, and 5 (Table 2). These proteins play a key role in organizing actin filaments during clathrin-mediated endocytosis and the formation of pseudopods $(23,24)$.

EGFR was also associated with numerous actin-binding proteins, including $\alpha$-actinin, calponin 3, cofilin-1, drebrin, and fascin (Table 2). The association of EGFR with filamins A and B, which link actin to membrane glycoproteins (25), suggests that these both may connect EGFR with actin and its associated proteins. Actin dynamics are known to be regulated by small GTPases (26), and we found that EGFR was associated with RhoA, RhoB, RhoC, RhoG, RAC1, 
TABLE 2 List of selected proteins that had constitutive association with EGFR in response to infection with C. albicans

\begin{tabular}{|c|c|c|c|c|c|c|c|c|}
\hline \multirow[b]{3}{*}{ Function/location } & \multirow{3}{*}{$\begin{array}{l}\text { Accession } \\
\text { no. }\end{array}$} & \multirow[b]{3}{*}{ Gene } & \multirow[b]{3}{*}{ Protein } & \multicolumn{5}{|c|}{ Result for ${ }^{a}$ : } \\
\hline & & & & \multicolumn{3}{|c|}{$\begin{array}{l}\text { C. albicans } \\
\text { replicate }\end{array}$} & \multicolumn{2}{|c|}{$\begin{array}{l}\text { EGF- } \\
\text { incubated } \\
\text { replicate }\end{array}$} \\
\hline & & & & 1 & 2 & 3 & 1 & 2 \\
\hline \multirow[t]{2}{*}{ Receptor } & P29317 & EPHA2 & Ephrin type-A receptor 2 & 1.65 & 0.68 & 0.44 & 0.58 & 0.33 \\
\hline & D3XNU5 & $\mathrm{CDH} 1$ & E-cadherin 1 & 0.48 & 0.79 & 0.64 & 0.43 & 0.42 \\
\hline \multirow[t]{2}{*}{ Src tyrosine kinase } & P07948-2 & $L Y N$ & Isoform 2 of tyrosine-protein kinase Lyn & 6.58 & 0.68 & 0.63 & 0.57 & 0.58 \\
\hline & B2RA70 & YES1 & $\begin{array}{l}\text { Highly similar to Homo sapiens v-yes-1 } \\
\text { Yamaguchi sarcoma viral oncogene } \\
\text { homolog } 1\end{array}$ & 4.23 & 0.65 & 0.53 & 0.75 & 0.46 \\
\hline \multirow[t]{2}{*}{ Lipid rafts } & Q03135 & CAV1 & Caveolin-1 & 1.62 & 1.22 & 0.87 & 1.19 & 0.83 \\
\hline & P61586 & RHOA & RhoA & 1.90 & 0.96 & 0.66 & 0.89 & 0.77 \\
\hline \multirow[t]{5}{*}{ Clathrin internalization pathway } & Q00610-2 & CLTC & Isoform 2 of clathrin heavy chain 1 & 1.69 & 0.88 & 0.80 & 2.22 & 1.12 \\
\hline & P09496-2 & CLTA & Isoform non-brain of clathrin light chain A & 4.64 & 1.05 & 1.61 & 2.72 & 1.55 \\
\hline & P09497-2 & CLTB & Isoform non-brain of clathrin light chain B & Inf & 0.94 & 1.20 & 2.03 & 1.44 \\
\hline & Q14247 & $C T T N$ & Cortactin & 3.56 & 1.31 & 0.90 & 0.39 & 0.39 \\
\hline & B5BU72 & PICALM & $\begin{array}{l}\text { Phosphatidylinositol-binding clathrin } \\
\text { assembly protein isoform } 2\end{array}$ & 1.61 & 0.75 & 1.12 & 2.18 & 1.44 \\
\hline \multirow[t]{3}{*}{ Actin-related protein $2 / 3$ complex } & P61160 & ACTR2 & Actin-related protein 2 & 2.96 & 1.12 & 0.94 & 0.61 & 0.50 \\
\hline & P61158 & ACTR3 & Actin-related protein 3 & 1.93 & 1.17 & 0.55 & 0.43 & 0.49 \\
\hline & 015143 & $A R P C 1 B$ & Actin-related protein $2 / 3$ complex subunit $1 B$ & 2.14 & 1.75 & 1.06 & 0.58 & 0.36 \\
\hline \multirow{4}{*}{ Actin-binding protein } & P23528 & CFL1 & Cofilin-1 & 1.72 & 0.70 & 0.58 & 1.08 & 0.88 \\
\hline & Q16643 & DBN1 & Drebrin & 1.51 & 1.39 & 1.08 & 0.00 & 0.00 \\
\hline & P21333-2 & FLNA & Isoform 2 of filamin-A & 3.46 & 1.02 & 1.02 & 0.61 & 0.55 \\
\hline & O75369-2 & FLNB & Isoform 2 of filamin-B & 4.18 & 1.08 & 1.38 & 0.74 & 0.61 \\
\hline \multirow[t]{7}{*}{ Regulator of actin dynamics } & P62745 & $R H O B$ & RhoB & 1.96 & 0.56 & 0.89 & 0.76 & 0.86 \\
\hline & Q5JR08 & RHOC & RhoC & 1.80 & 0.96 & 0.80 & 0.85 & 0.86 \\
\hline & P84095 & RHOG & RhoG & 1.30 & 0.78 & 5.60 & 0.74 & 0.40 \\
\hline & P63000 & $R A C 1$ & Ras-related C3 botulinum toxin substrate 1 & 1.98 & 0.70 & 0.90 & 0.85 & 0.71 \\
\hline & P15153 & $R A C 2$ & Ras-related C3 botulinum toxin substrate 2 & 1.87 & 0.74 & 1.30 & 0.73 & 0.83 \\
\hline & P62826 & $\operatorname{RAN}$ & Ran & 1.16 & 0.73 & 0.68 & 0.58 & 0.98 \\
\hline & P60953 & $C D C 42$ & Cell division control protein 42 & 1.49 & 0.61 & 1.00 & 0.88 & 0.86 \\
\hline \multirow[t]{5}{*}{ Small GTPase } & P01112 & HRAS & H-Ras & 2.55 & 0.37 & 0.99 & 0.40 & 0.96 \\
\hline & P01116-2 & KRAS & K-Ras & 3.46 & 0.33 & 0.83 & 0.78 & 0.84 \\
\hline & P01111 & NRAS & N-Ras & 3.06 & 0.40 & 0.83 & 0.56 & 0.82 \\
\hline & P10301 & RRAS & Ras-related protein R-Ras & 2.36 & 0.98 & 1.00 & 0.34 & 1.01 \\
\hline & P62070 & RRAS2 & Ras-related protein R-Ras2 & 1.66 & 0.59 & 0.83 & 0.31 & 0.64 \\
\hline \multirow[t]{2}{*}{ Guanine nucleotide exchange factor } & Q86TW5 & ARHGEF16 & Rho guanine nucleotide exchange factor 16 & 2.96 & 0.99 & 1.10 & 1.17 & 1.04 \\
\hline & P18754 & $R C C 1$ & Regulator of chromosome condensation & 2.46 & $\operatorname{lnf}$ & 0.58 & $\operatorname{lnf}$ & 1.00 \\
\hline
\end{tabular}

aShown are individual results from 3 biological replicates for epithelial cells infected with C. albicans and 2 biological replicates from epithelial cells incubated with EGF. Values are the ratio of the amount of protein detected in cells exposed to C. albicans or EGF relative to unstimulated control cells. "Inf" (i.e., "infinite change") indicates proteins that were undetectable in unstimulated control cells. 

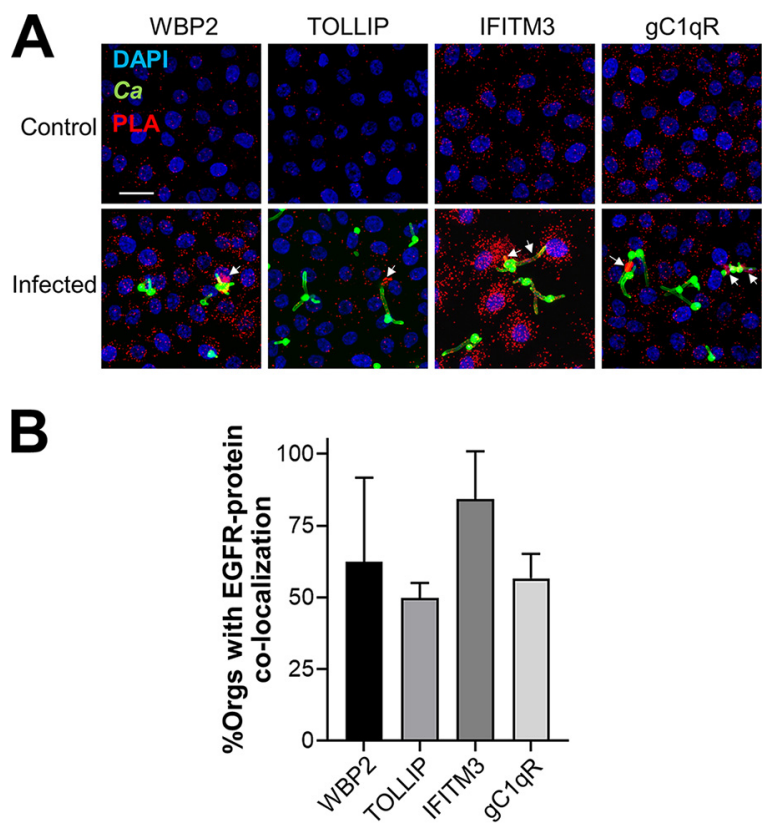

FIG 1 Proximity ligation assays (PLA) showing the physical association of the epidermal growth factor receptor (EGFR) with WW domain-binding protein 2 (WBP2), Toll-interacting protein (TOLLIP), interferon-induced transmembrane protein 3 (IFITM3), and the globular C1q receptor (gC1qR) in the OKF6/TERT-2 oral epithelial cell line. (A) Confocal microscopic images of epithelial cells that had been either incubated with medium alone (top) or infected with C. albicans (bottom) for $90 \mathrm{~min}$. Red spots indicate the regions where the indicated proteins associate with EGFR. Arrows indicate the accumulation of the proteins around C. albicans hyphae. Results are representative of three independent experiments. Scale bar, $25 \mu \mathrm{m}$. (B) Quantitative analysis of the images to determine the percentage of $C$. albicans cells with spots indicating the colocalization of EGFR with WBP2, TOLLIP, IFITM3, or gC1qR. Results are the mean \pm SD from three independent experiments. Ca, C. albicans; Orgs, organisms.

RAC2, Ran, and CDC42 (Table 2). EGFR associated with additional small GTPases, including H-Ras, K-Ras, N-Ras, R-Ras, R-Ras2 and 28 different Rabs (Table 2). Most small GTPases require guanine nucleotide-exchange factors (GEFs) for activation (27), and EFGR associated with guanine nucleotide exchange factor 16 (neuroblastoma, ephexin 4) and regulator of chromosome condensation 1 (RCC1) (Table 2). Collectively, these results indicate that EGFR has extensive interactions with the actin cytoskeleton and its regulatory proteins that likely induce the endocytosis of $C$. albicans hyphae and secretion of proinflammatory mediators when EGFR is activated.

The EGFR-associated proteins WBP2, TOLLIP, IFITM3, and gC1qR govern the epithelial cell response to $C$. albicans. Among the proteins that were predicted by the proteomics data to have increased association with EGFR in response to C. albicans, we selected six for additional study: WBP2, guanylate binding protein 6 (GBP6), TOLLIP, early endosome antigen 1 (EEA1), desmoglein-3 (DSG3), and IFITM3. These proteins were chosen because of their potential roles in governing the endocytosis of $C$. albicans and the secretion of proinflammatory mediators. We also investigated the globular $\mathrm{C} 1 \mathrm{q}$ receptor $(\mathrm{gC} 1 \mathrm{qR})$, which was constitutively associated with EGFR. Our rationale was that $\mathrm{gC1qR}$ is known to function as a receptor for Listeria monocytogenes, and there are significant similarities between the mechanisms of host cell invasion by this bacterium and by C. albicans (18, 21, 28-30).

To verify that the selected proteins were associated with EGFR in intact oral epithelial cells and to determine their subcellular location with respect to $C$. albicans cells, we used a proximity ligation assay (16). This assay forms a fluorescent spot where two proteins are located within $40 \mathrm{~nm}$ of one another (31). All seven proteins were associated with EGFR in both infected and uninfected epithelial cells, but only WBP2, TOLLIP, IFITM3, and gC1qR accumulated with EGFR in the vicinity of $C$. albicans hyphae (Fig. 1; see Fig. S1 in the supplemental material). The accumulation of WBP2, TOLLIP, IFITM3, and $\mathrm{gC} 1 \mathrm{qR}$ around $C$. albicans suggested that these proteins might govern the epithelial cell response to the fungus. 
To investigate this hypothesis, we used small interfering (siRNA) to knock down the levels of each these proteins in the OKF6/TERT-2 human oral epithelial cell line. We then measured C. albicans adherence to epithelial cells and subsequent endocytosis using a standard differential fluorescence assay $(18,22)$. We also analyzed the secretion of IL- $1 \beta$ and IL- 8 by enzyme-linked immunosorbent assay (ELISA). As a control, we used siRNA to knock down EGFR in the epithelial cells. Consistent with previous results $(13,16)$, knockdown of EGFR modestly reduced the number of cell-associated $C$. albicans cells (a measure of adherence) and decreased the number of endocytosed organisms by almost $50 \%$ (Fig. 2A). Reduction of EGFR also inhibited C. albicans-induced secretion of IL-8 but not IL-1 $\beta$.

WBP2 is a multifunctional protein that has mainly been studied in the context of breast cancer. Functioning as an adapter protein and transcriptional coactivator, WBP2 is required for maximal EGFR expression and for the normal activity of the phosphatidylinositol 3-kinase (PI3K)/Akt signaling pathway (32). WBP2 also links Jun N-terminal protein kinase (JNK) to Wnt signaling (32). Both PI3K/Akt and JNK have been shown to govern the response of oral epithelial cells to $C$. albicans $(33,34)$. As shown, siRNA knockdown of WBP2 reduced total EGFR levels in oral epithelial cells, leading to a decrease in C. albicans endocytosis and a reduction in IL-1 $\beta$ and IL-8 production (Fig. 2B). Thus, knockdown of WBP2 largely phenocopies the knockdown of EGFR and is required for normal cellular EGFR levels in oral epithelial cells.

TOLLIP is a membrane-associated endocytic adapter protein that is a negative regulator of the innate immune response. TOLLIP inhibits signaling by STAT1, Toll-like receptors, and IL-1 $\beta$ (35-37), but was not previously known to associate with EGFR. Knockdown of TOLLIP inhibited secretion of IL-8 but had no impact on the adherence or endocytosis of $C$. albicans or the secretion of IL-1 $\beta$ (Fig. $2 \mathrm{C}$ ). These results suggest that TOLLIP is a positive regulator of epithelial cell IL-8 secretion in response to $C$. albicans infection.

IFITM3 plays a key role in the host defense against viral infections by binding to virus particles and shuttling them to lysosomes for degradation (38). By a similar process, IFITM3 also enhances the degradation of activated EGFR (38). Knockdown of IFITM3 in oral epithelial cells had paradoxical effects. Although loss of IFITM3 inhibited the adherence and endocytosis of $C$. albicans, it stimulated C. albicans-induced secretion of IL-1 $\beta$ and IL-8 (Fig. 2D), thereby dissociating the process of endocytosis from cytokine production.

$\mathrm{gC1qR}(\mathrm{HABP} 1 / \mathrm{p} 32)$ is present in the mitochondrial matrix where is involved in oxidative phosphorylation (39). Although gC1qR lacks a transmembrane sequence, it is also expressed on the cell surface, where it functions as a receptor for $\mathrm{C} 1 \mathrm{q}$, high-molecular weight kininogen, factor XII, vitronectin, and hyaluronic acid (40-43). gC1qR also acts as a host cell receptor for multiple pathogens, including L. monocytogenes, Staphylococcus aureus, and Plasmodium falciparum $(28,44,45)$. In carcinoma cells, inhibition of gC1qR with a monoclonal antibody is known to reduce EGFR phosphorylation and block stimulation of migration and formation of lamellipodia in response to EGF (46). We found that siRNA knockdown of gC1qR inhibited the endocytosis of $C$. albicans but stimulated the secretion of IL-1 $\beta$ and IL-8 (Fig. 2E), suggesting that gC1qR may play a key role in the activation of EGFR by $C$. albicans.

Surface-exposed $\mathrm{gC1qR}$ is required for EGFR-mediated endocytosis of $\boldsymbol{C}$. albicans. Because gC1qR functions as a host cell receptor for several microbial pathogens and was required for the maximal endocytosis of $C$. albicans, we focused on this protein for in-depth study. $\mathrm{gC1qR}$ is expressed both on the cell surface and intracellularly. Thus, the $\mathrm{gC} 1 \mathrm{qR}$ siRNA likely reduced the levels of both cell surface and intracellular gC1qR. To test whether the inhibition of just surface-exposed gC1qR altered the epithelial cell response to C. albicans, we evaluated two different anti-gC1qR monoclonal antibodies, 60.11 and 74.5.2, which bind to different domains of gC1qR (47). Both antibodies decreased the endocytosis of C. albicans (Fig. 3A), and antibody 74.5.2 slightly reduced the number of cell-associated organisms (see Fig. S2A in the supplemental material). Also, treating the epithelial cells with both monoclonal antibodies together did not result in a further inhibition of endocytosis. Thus, surface-exposed $\mathrm{gC} 1 \mathrm{qR}$ is required for maximal endocytosis of $C$. albicans by oral epithelial cells.

To investigate the functional relationship between $\mathrm{gC1qR}$ and EGFR, we treated the oral epithelial cells with an anti-gC1qR monoclonal antibody, the specific EGFR inhibitor gefitinib, or the antibody and gefitinib in combination. Both the anti-gC1qR antibody and gefitinib 
A EGFR

EGFR

GAPDH

\section{WBP2}

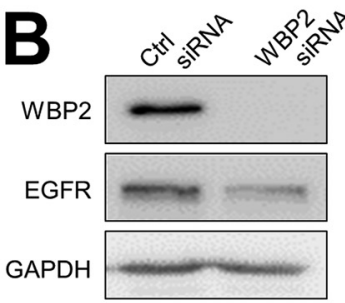

TOLLIP

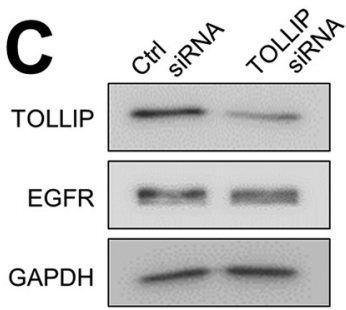

IFITM3

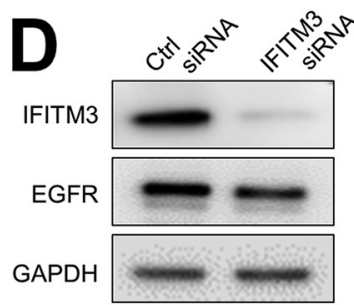

gC1qR

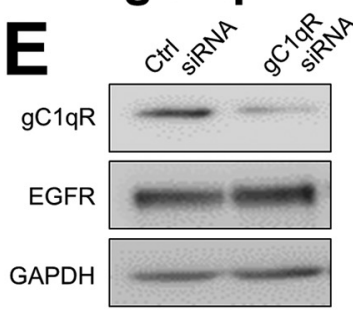

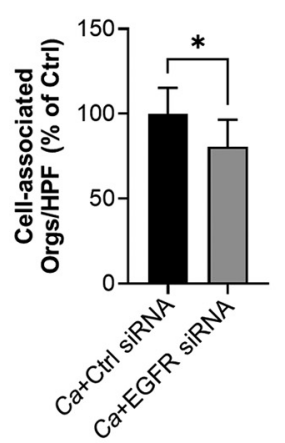
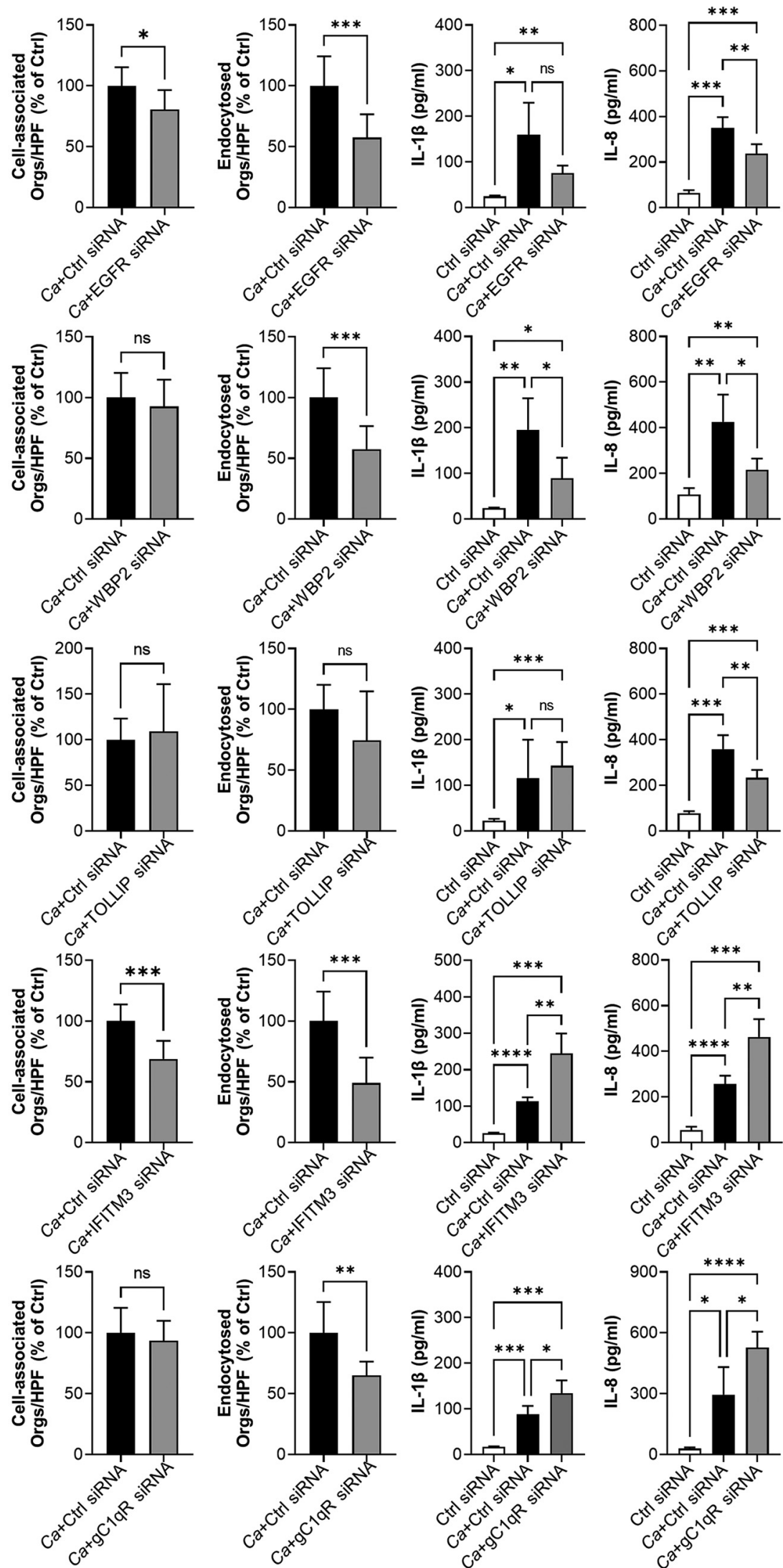
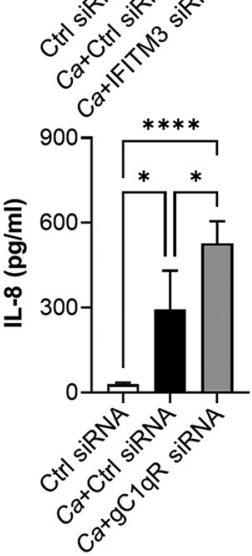

FIG 2 Functional analysis of proteins that interact with EGFR. Oral epithelial cells were transfected with EGFR (A), WBP2 (B), TOLLIP (C), IFITM3 (D), and gC1qR (E) siRNA. For each siRNA, the extent of protein knockdown and its effects on the number of 

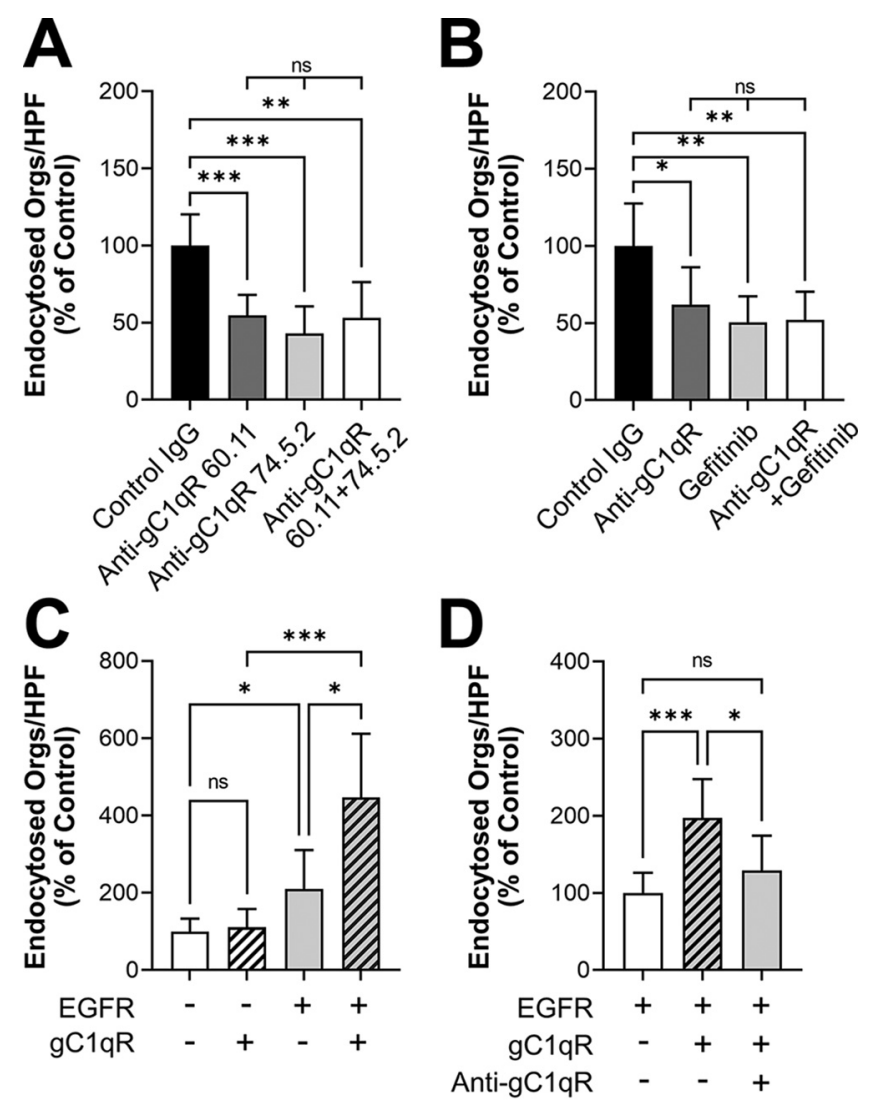

FIG 3 Surface-expressed gC1qR mediates the endocytosis of $C$. albicans. (A) Effects of two different anti-gC1qR monoclonal antibodies on the endocytosis of $C$. albicans by oral epithelial cells. (B) Effects of the anti-gC1qR antibody 74.5.2 and the EGFR kinase inhibitor gefitinib on the endocytosis of $C$. albicans by oral epithelial cells. (C and D) Endocytosis of $C$. albicans by $\mathrm{NIH} / 3 \mathrm{~T} 3$ cells expressing human gC1qR and/or human EGFR. (C) Additive effects of EGFR and gC1qR on endocytosis. (D) Effects of inhibiting surface-expressed gC1qR with the anti-gC1qR antibody 74.5.2 on endocytosis. Results are the mean \pm SD from three independent experiments, each performed in triplicate. The data were analyzed using one-way analysis of variance with Dunnett's test for multiple comparisons. ns, not significant; Orgs/HPF, organisms per high-power field; ${ }^{*}, P<0.05 ;{ }^{* *}, P<0.01 ;{ }^{* * *}, P<0.001$.

inhibited the endocytosis of $C$. albicans similarly, and combining the anti-gC1qR antibody with gefitinib did not decrease endocytosis further (Fig. 3B). None of the treatments altered the number of cell-associated organisms (Fig. S2B). These results suggest that gC1qR may function in the same pathway as EGFR to mediate the endocytosis of $C$. albicans.

We further explored the relationship between gC1qR and EGFR in the endocytosis of $C$. albicans using a heterologous expression approach. We obtained two NIH/3T3 mouse fibroblastoid cell lines: a wild-type cell line and one that had been transfected with human EGFR and HER2 (48). Each of these cell lines was then transfected with either green fluorescent protein (GFP) as a control or human gC1qR. When wild-type $\mathrm{NIH} / 3 \mathrm{~T} 3$ cells were transfected with gC1qR, they endocytosed a similar number of $C$. albicans cells to the control cells (Fig. $3 C$ ), indicating that gC1qR was unable to induce endocytosis in the absence of EGFR. As we found previously (13), $\mathrm{NIH} / 3 \mathrm{~T} 3$ cells that expressed human EGFR and HER2 endocytosed more $C$. albicans cells than the wild-type cells. When the EGFR-expressing cells were transfected with gC1qR, they endocytosed even more organisms. This increase in endocytosis was due to the

FIG 2 Legend (Continued)

cell-associated organisms, the number of endocytosed organisms, IL-1 $\beta$ secretion, and IL-8 secretion were determined. The graphs show the mean \pm SD from three independent experiments, each performed in triplicate. The data were analyzed using one-way analysis of variance with Dunnett's test for multiple comparisons. Ca, C. albicans; Ctrl, control; ns, not significant; Orgs/HPF, organisms per high-power field; ${ }^{*}, P<0.05 ;{ }^{* *}, P<0.01 ;{ }^{* * *}, P<0.001 ;{ }^{* * * *}, P<0.0001$. 


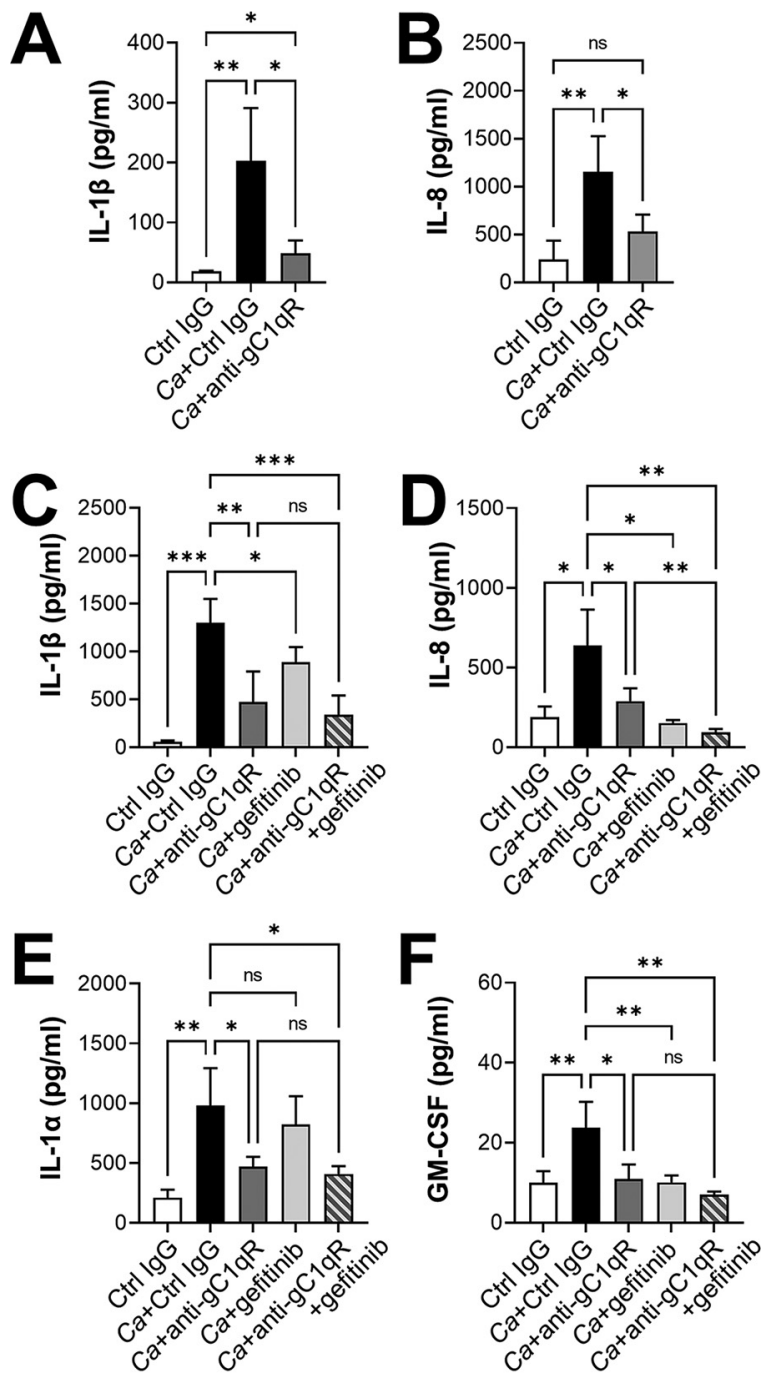

FIG $4 \mathrm{gClqR}$ is required for production of proinflammatory mediators by oral epithelial cells in response to $C$. albicans infection. (A to F) Oral epithelial cells were infected with $C$. albicans in the presence of the anti-gC1qR antibody 74.5 .2 or gefitinib for $8 \mathrm{~h}$, after which the concentration of the indicated inflammatory mediators in the medium was analyzed by ELISA (A and B) or Luminex cytometric bead array (C to F). Results are the mean \pm SD from three independent experiments, each performed in duplicate. The data were analyzed using one-way analysis of variance with Dunnett's test for multiple comparisons. Ca, $\mathrm{C}$. albicans; Ctrl, control; ns, not significant; ${ }^{*}, P<0.05 ;{ }^{* *}, P<0.01 ;{ }^{* * *}, P<0.001$.

presence of surface-expressed gC1qR because treating these cells with an anti-gC1qR antibody reduced endocytosis to basal levels (Fig. 3D). There was an increase in the number of C. albicans cells that were associated with $\mathrm{NIH} / 3 \mathrm{~T} 3$ cells that expressed EGFR relative to cells that did not (Fig. S2C). However, expression of gC1qR had no significant effect on the number of cell-associated organisms (Fig. S2C and D). Collectively, these data indicate that $\mathrm{gC1qR}$ is a key cofactor that enhances EGFR-mediated endocytosis of $C$. albicans.

Surface-expressed $\mathrm{gC1qR}$ is required for C. albicans-induced stimulation of epithelial cell production of proinflammatory mediators. To investigate the role of surface-expressed gC1qR in the oral epithelial cell inflammatory response to $C$. albicans, we analyzed the effects of an anti-gC1qR antibody on the secretion of IL-1 $\beta$ and IL-8. In contrast to knockdown of gC1qR with siRNA, inhibiting gC1qR with the monoclonal antibody significantly reduced the secretion of both mediators, indicating that surfaceexpressed gC1qR is required for C. albicans to stimulate their production (Fig. 4A and B).

Next, we analyzed the functional relationship between gC1qR and EGFR in the epithelial cell proinflammatory response. We used a cytometric bead array to measure the levels of IL- $1 \beta$, IL-8, IL-1 $\alpha$, and granulocyte-macrophage colony-stimulating factor (GM- 

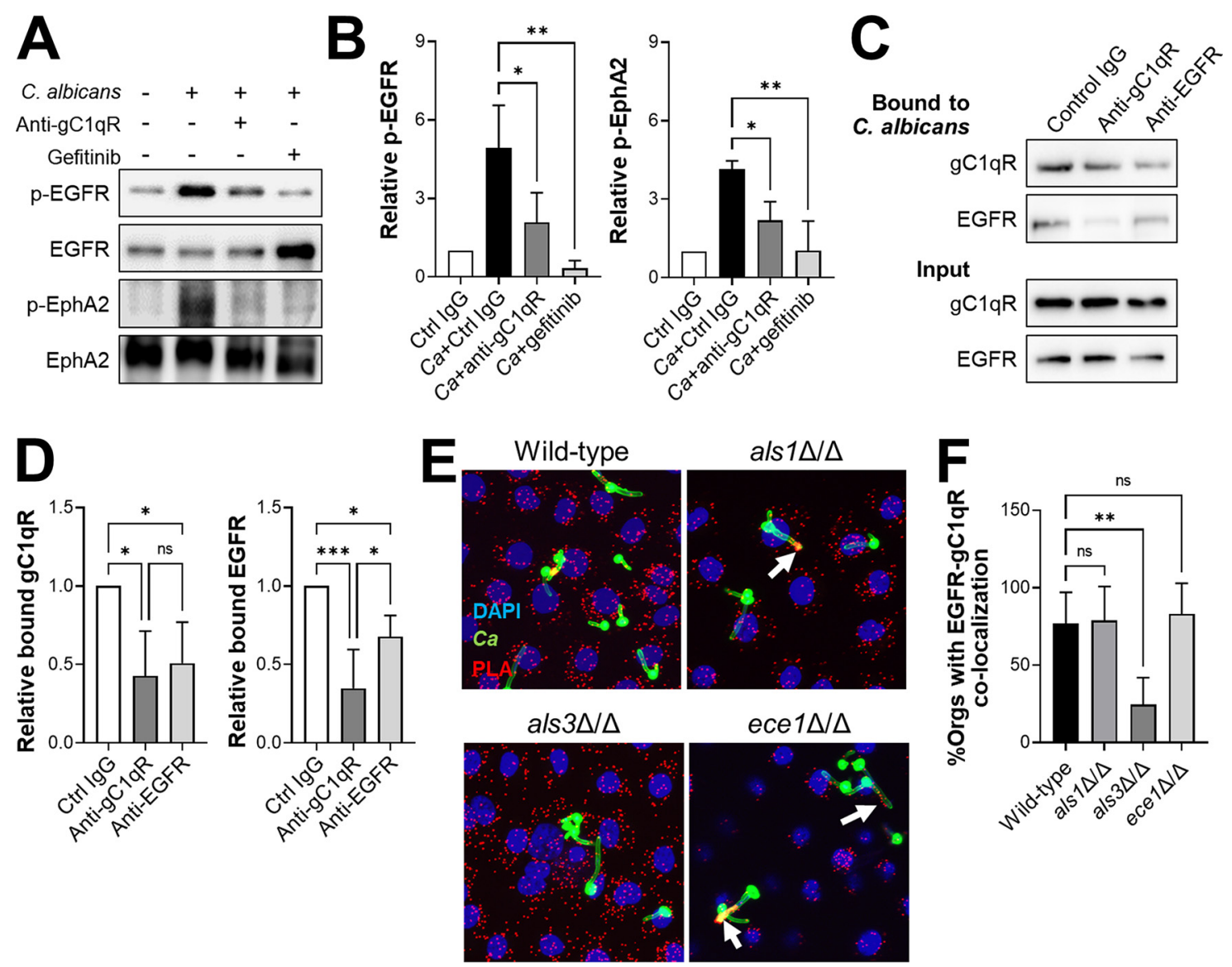

FIG 5 Interactions of gC1qR and EGFR with C. albicans. (A and B) Effects of the anti-gC1qR antibody 74.5 .2 and gefitinib on the phosphorylation of EGFR and EphA2 in response to 90-min infection with C. albicans. (A) Representative immunoblots. (B) Densitometric analysis of three immunoblots, such as the ones shown in panel A. (C and D) Effects of anti-gC1qR and anti-EGFR antibodies on binding of gC1qR and EGFR to C. albicans hyphae. (C) Representative immunoblots. (D) Densitometric analysis of four immunoblots, such as the ones shown in panel $C$. Results are the mean \pm SD from 3 to 4 independent experiments. (E and F) Representative confocal images of the proximity ligation assay (PLA) showing the association of $\mathrm{gC} 1 \mathrm{qR}$ with EGFR around hyphae of $C$. albicans wild-type, als $1 \Delta / \Delta$, and ece $1 \Delta / \Delta$ strains, but not the als $3 \Delta / \Delta$ mutant (E). (F) Quantitative analysis of the images such as the one in panel $E$ to determine the percentage of hyphae of the indicated C. albicans strains, with spots indicating the colocalization of EGFR with gC1qR. Results are the mean \pm SD from three independent experiments. The numerical data were analyzed using one-way analysis of variance with Dunnett's test for multiple comparisons. Ca, C. albicans; Ctrl, control; ns, not significant; Orgs, organisms; ${ }^{*}, P<0.05 ;{ }^{* *}, P<0.01 ;{ }^{* * *}, P<0.001$.

CSF) that were secreted in response to C. albicans. Inhibition of surface-expressed gC1qR significantly reduced the production of all four inflammatory mediators (Fig. $4 \mathrm{C}$ to F), although the absolute levels of IL- $1 \beta$ and IL- 8 were somewhat different when measured by the cytometric bead array instead of the ELISA. Inhibition of EGFR with gefitinib also significantly decreased the levels of IL- $1 \beta$, IL-8, and GM-CSF, but had no effect on IL- $1 \alpha$ levels, as reported previously $(15,16)$. The finding that inhibition of $\mathrm{gC} 1 \mathrm{qR}$ reduced IL- $1 \alpha$ production whereas inhibition of EGFR had no effect suggests that $\mathrm{gC} 1 \mathrm{qR}$ is required for the production of IL- $\alpha$ by interacting with a receptor other than EGFR.

When the epithelial cells were incubated with the anti-gC1qR antibody and gefitinib in combination, the production of IL-1 $\beta$ and GM-CSF was not inhibited more than in cells incubated with the anti-gC1qR antibody alone (Fig. 4C and F). However, dual inhibition of gC1qR and EGFR resulted in a modest further reduction in IL-8 production (Fig. 4F). Collectively, these results indicate that $\mathrm{gC} 1 \mathrm{qR}$ and EGFR function in the same pathway to induce the production of IL-1 $\beta, \mathrm{IL}-8$, and GM-CSF in response to $C$. albicans.

gC1qR is necessary for intact $C$. albicans to interact with EGFR. Our finding that $\mathrm{gC1qR}$ functions in the same pathway as EGFR to mediate epithelial cell endocytosis and stimulation prompted us to investigate whether $\mathrm{gC} 1 \mathrm{qR}$ was necessary for $C$. albicans to activate EGFR. We found that treatment of oral epithelial cells with an anti-gC1qR antibody decreased C. albicans-induced phosphorylation of EGFR by approximately 58\% (Fig. 5A and C). As 
expected, treatment of the infected cells with the EGFR kinase inhibitor gefitinib reduced EGFR phosphorylation to below basal levels. Notably, inhibition of gC1qR did not block EGFR phosphorylation in response to either EGF or candidalysin, a pore-forming toxin released by $C$. albicans $(15,49)$ (see Fig. S3 in the supplemental material). Thus, the effects of inhibiting surface-expressed gC1qR were specific to intact C. albicans.

Activation of EGFR is also required for $C$. albicans to induce sustained phosphorylation of the EphA2 receptor tyrosine kinase $(11,16)$. We determined that inhibition of gC1qR decreased C. albicans-induced EphA2 phosphorylation (Fig. 5A and B). These findings are consistent with the model that $\mathrm{gC} 1 \mathrm{qR}$ is necessary for $C$. albicans to activate EGFR and its downstream signaling pathways in oral epithelial cells.

Previously, we found that EGFR associated, either directly or indirectly, with C. albicans hyphae (13). To determine if $\mathrm{gClqR}$ plays a role in this association, we infected oral epithelial cells with C. albicans in the presence of either an anti-gC1qR antibody or an anti-EGFR antibody. After 90 min, we lysed the epithelial cells with a detergent, collected the $C$. albicans hyphae, and rinsed them extensively to remove unbound proteins. Using high-molar urea, we eluted the epithelial cell proteins that remained associated with the organisms and analyzed them by immunoblotting. In control cells, both gC1qR and EGFR were associated with the C. albicans hyphae (Fig. 5C and D). When the cells were incubated with the anti-gC1qR antibody, there was a significant reduction in the amounts of $\mathrm{gC1qR}$ and EGFR that were associated with C. albicans. When the cells were incubated with an anti-EGFR antibody, the amounts of fungusassociated gC1qR and EGFR were also significantly reduced. Collectively, these data suggest that $\mathrm{gC} 1 \mathrm{qR}$ and EGFR have a reciprocal relationship such that each protein is necessary for the other to maximally associate with $C$. albicans.

C. albicans Als3 but not candidalysin is required for increased association of gC1qR with EGFR. Both the Als3 invasin and the candidalysin pore-forming toxin are required for $C$. albicans to maximally activate EGFR in oral epithelial cells $(15,16)$. We investigated whether these factors were required for $\mathrm{gC} 1 \mathrm{qR}$ to associate with EGFR around C. albicans cells in intact oral epithelial cells. Using the proximity ligation assay, we determined that when oral epithelial cells were infected with an als $3 \Delta / \Delta$ deletion mutant, there was minimal accumulation of the gC1qR-EGFR-containing complex around the hyphae (Fig. 5E and F). In contrast, when the epithelial cells were infected with the wild-type strain, an als $1 \Delta / \Delta$ deletion mutant, or a candidalysin-deficient ece $1 \Delta / \Delta$ deletion mutant, this complex formed around the hyphae. Thus, Als3, but not Als1 or candidalysin, is necessary for gC1qR to associate with EGFR around C. albicans hyphae.

Inhibition of $\mathbf{g C 1 q R}$ does not alter C. albicans virulence or activation of EGFR in mice. Next, we investigated the role of $\mathrm{gC} 1 \mathrm{qR}$ in the pathogenesis of oropharyngeal candidiasis in mice. To verify that monoclonal antibodies raised against human $\mathrm{gC} 1 \mathrm{qR}$ could inhibit mouse $\mathrm{gC} 1 \mathrm{qR}$, we tested the capacity of these antibodies to inhibit the endocytosis of $C$. albicans by primary mouse epithelial cells. We found monoclonal antibody 74.5.2, which is directed against the binding site for high-molecular-weight kininogen (47), significantly reduced C. albicans endocytosis (Fig. 6A). It also decreased the number of cell-associated organisms (see Fig. S4 in the supplemental material). In contrast, monoclonal antibody 60.11, which recognizes the binding site for C1q (47), had no detectable effect on either interaction.

Based on these results, we treated immunocompetent mice with antibody 74.5.2 and orally infected them with wild-type C. albicans. Control mice were treated with either mouse IgG or gefitinib. We found that after 1 day of infection, mice treated with the anti-gC1qR antibody had the same oral fungal burden as mice that received the control lgG (Fig. 6B). The level of myeloperoxidase (MPO), a measure of phagocyte accumulation $(50,51)$, in the oral tissues was also not changed by administration of the anti-gC1qR antibody (Fig. 6C). As expected (16), treatment with gefitinib significantly reduced both the oral fungal burden and oral MPO levels in the mice. These results suggest the $\mathrm{gC} 1 \mathrm{qR}$ is dispensable for mediating the epithelial cell response to C. albicans in mice. 

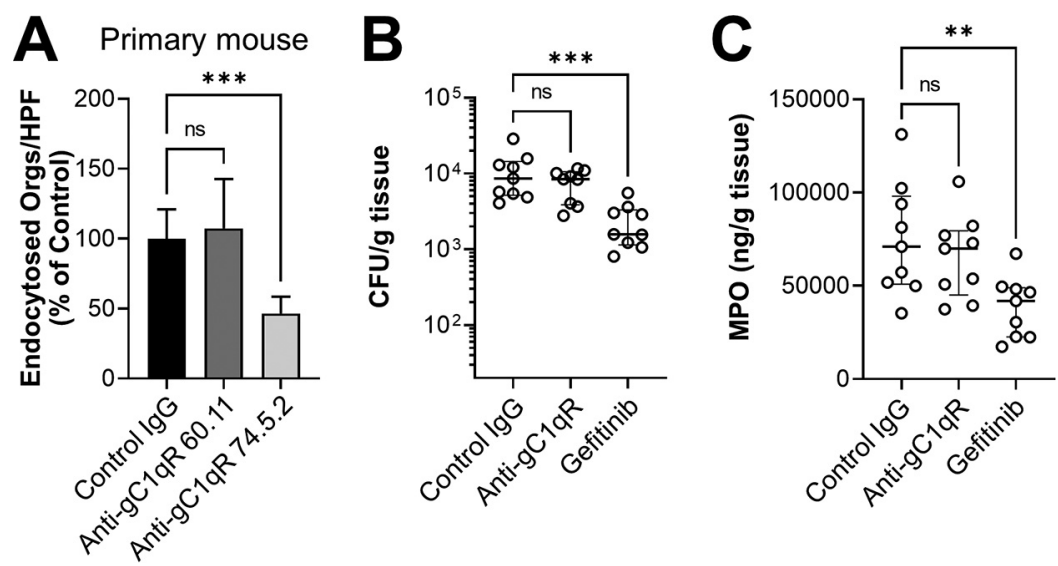

FIG 6 Inhibition of gC1qR has no significant effect on the outcome of oropharyngeal candidiasis. (A) Effects of the indicated anti-gC1qR antibodies on the endocytosis of C. albicans by primary mouse oral epithelial cells. Results are the mean \pm SD from three independent experiments, each performed in triplicate. The data were analyzed using one-way analysis of variance with Dunnett's test for multiple comparisons. ( $B$ and $C$ ) Effects of the anti-gC1qR antibody 74.5.2 and gefitinib on the outcome of oropharyngeal candidiasis after 1 day of infection as shown by oral fungal burden (B) and oral myeloperoxidase (MPO) content (C). Results are the median \pm interquartile range from two independent experiments, each with 4 to 5 mice per group. The data were analyzed using the Kruskal-Wallis test. ns, not significant; Orgs/HPF, organisms per high-power field; ${ }^{* *}, P<0.01 ;{ }^{* * *}, P<0.001$.

Human oral epithelial cells respond differently to $C$. albicans than mouse oral epithelial cells. One potential explanation for the lack of efficacy of the anti-gC1qR antibody in mice is that EGFR signaling pathways differ between mouse and human oral epithelial cells. To investigate this possibility, we analyzed the effects of knocking down or inhibiting both gC1qR and IFITM3 in human and mouse oral epithelial cells. Because our original experiments were performed with the human OKF6/TERT-2 oral epithelial cell line, we first verified that primary human oral epithelial cells responded similarly to this cell line. We found that treatment of primary human oral epithelial cells with the anti-gC1qR antibody reduced $C$. albicans-induced phosphorylation of EGFR and C. albicans endocytosis (Fig. 7A to C) but had a nonsignificant effect on adherence (Fig. S4B), similar to its activity on the OKF6/TERT-2 cell line (Fig. 3A and Fig. 5A and B). Thus, gC1qR is necessary for $C$. albicans to activate EGFR and induce the endocytosis of C. albicans by human oral epithelial cells.

Next, we tested the capacity of the anti-gC1qR antibody 74.5 .2 to inhibit C. albicansinduced phosphorylation of EGFR in primary mouse epithelial cells. We determined that the antibody had no effect, although EGFR phosphorylation was inhibited by gefitinib (Fig. 7D and $\mathrm{E})$. Knockdown of gC1qR in mouse epithelial cells also failed to reduce EGFR phosphorylation in responses to C. albicans (Fig. S4C and D). Collectively, these data indicate that in mice, gC1qR is likely dispensable for C. albicans-induced EGFR activation, unlike in humans.

These results prompted us to investigate whether IFITM3 also functioned differently in human versus mouse oral epithelial cells. In OKF6/TERT-2 cells, knockdown of IFITM3 did not decrease the levels of total or phosphorylated EGFR, so we did not investigate this response further (see Fig. S5A and B in the supplemental material). In primary human oral epithelial cells, siRNA knockdown of IFITM3 inhibited the endocytosis of C. albicans (Fig. 7F), similarly to its effects on the human OKF6/TERT-2 oral epithelial cell line (Fig. 2D). However, knockdown of IFITM3 in primary human epithelial cells did not inhibit adherence (Fig. S5C). In mouse oral epithelial cells, knockdown of IFITM3 had no effect on the endocytosis or adherence of C. albicans (Fig. S5D and E). These results suggest that gC1qR and IFITM3 function differently in human oral epithelial cells than in mouse oral epithelial cells.

\section{DISCUSSION}

In this work, we determined that EGFR interacts with numerous proteins that function in a multitude of different signaling pathways, consistent with the concept that 

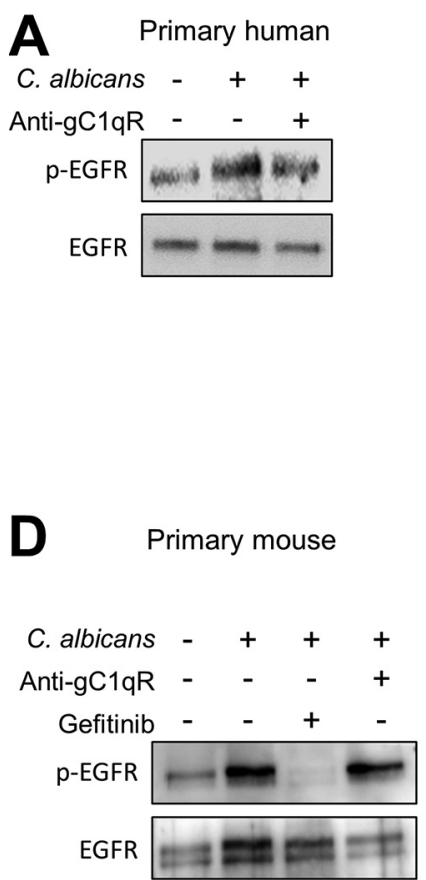

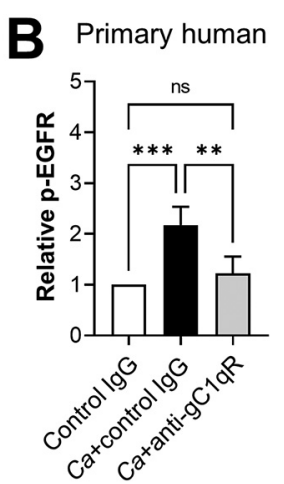

E Primary mouse

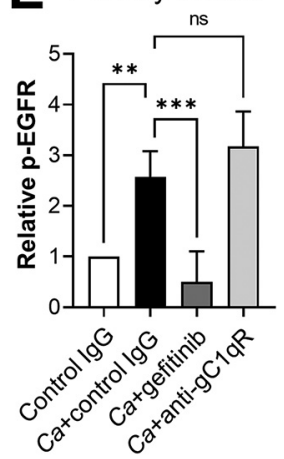

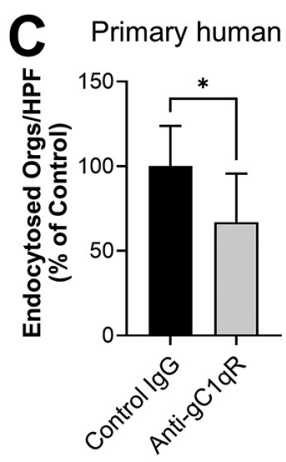

E Primary human

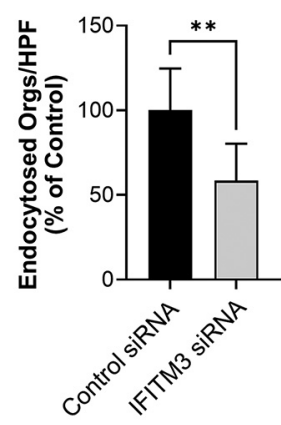

FIG 7 Mouse and human oral epithelial cells respond differently to C. albicans. (A and B) Effects of the anti-gC1qR antibody 74.5.2 on the phosphorylation of EGFR in primary human oral epithelial cells in response to 90-min infection with C. albicans. (A) Representative immunoblots. (B) Densitometric analysis of four immunoblots, such as the ones shown in panel A. (C) The anti-gC1qR antibody 74.5.2 inhibits the endocytosis of C. albicans by primary human oral epithelial cells. (D and E) Effects of the anti-gC1qR antibody 74.5 .2 and gefitinib on the phosphorylation of EGFR in primary mouse oral epithelial cells in response to 90-min infection with C. albicans. (D) Representative Western blots. (E) Densitometric analysis of four Western blots, such as the ones shown in panel D. (F) Effects of siRNA knockdown of IFITM3 on primary human oral epithelial cells. Results are the mean \pm SD from three independent experiments, each performed in triplicate. The data were analyzed using one-way analysis of variance with Dunnett's test for multiple comparisons. Ca, C. albicans; ns, not significant; Orgs/HPF, organisms per high-power field; ${ }^{*}, P<0.05 ;{ }^{* *}, P<0.01 ;{ }^{* * *}, P<0.001$.

this receptor is a key regulator of epithelial cell physiology. The proteomics data indicate that EGFR is part of a multiprotein complex that contains E-cadherin, EphA2, and HER2. This result provides an explanation for our previous findings that these three receptors function with EGFR in the same pathway to induce the epithelial cell response to $C$. albicans $(11,13,18)$.

Previously, we had determined that $C$. albicans activates the aryl hydrocarbon receptor, leading to the derepression of Src family kinases that phosphorylate EGFR (14). However, the member(s) of the Src family responsible for this phosphorylation remained unknown. The current finding that Lyn and Yes associate with EGFR suggests that these two members of the Src family kinases phosphorylate EGFR in response to C. albicans infection.

EGFR mediates the endocytosis of $C$. albicans by activating the cortactin-clathrin pathway, leading to the formation of pseudopods that engulf the organism and pull it into the epithelial cell $(21,22)$. The proteomics data were consistent with this mechanism and suggest that the arp2/3 complex mediates the rearrangement of actin filaments that induce pseudopod formation. Although the arp2/3 complex can be activated by the Wiskott-Aldrich syndrome protein (WASP) or vasodilator-stimulated phosphoprotein (VASP) (52-54), neither protein was consistently associated with EGFR in cells infected with $C$. albicans. Thus, it remains to be determined how EGFR activates this complex. 


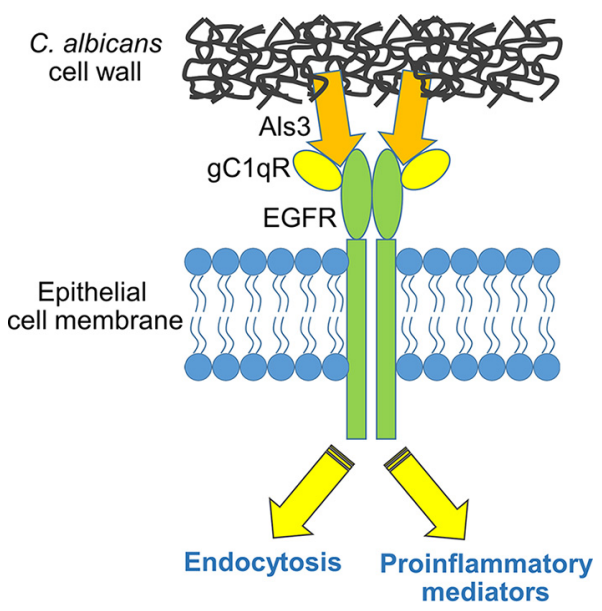

FIG 8 Diagram of the functional interaction of $C$. albicans Als3 with gC1qR and EGFR in human oral epithelial cells. Als3 interacts either directly or indirectly with both gC1qR and EGFR, leading to the activation of EGFR and subsequent induction of endocytosis and secretion of proinflammatory mediators.

We also established roles for four key proteins that interact with EGFR and induce the epithelial cell response to $C$. albicans, none of which had been previously implicated in the response to fungal pathogens. Three of these proteins, WBP2, IFITM3, and $\mathrm{gC} 1 \mathrm{qR}$, were required for maximal epithelial cell endocytosis of the fungus, suggesting that they function along with EGFR to orchestrate this process.

Perhaps not surprisingly, siRNA knockdown of these proteins had pleiotropic effects on the production of IL- $1 \beta$ and IL- 8 by the infected oral epithelial cells, as these are regulated by a myriad of inflammatory and infectious signals. Knockdown of WBP2 led to reduced cellular levels of EGFR and thus resulted in decreased production of IL- $1 \beta$ and IL-8, similar to siRNA knockdown of EGFR itself. This result is consistent with a report that WBP2 is required for normal EGFR expression (32).

Knockdown of TOLLIP inhibited the production of IL-8 but had no effect on IL- $1 \beta$ secretion. Although TOLLIP is generally considered to be a negative regulator of the host inflammatory response (35-37), our results suggest that it has the capacity to be a positive regulator of IL-8 production in epithelial cells infected with C. albicans.

While siRNA knockdown of IFITM3 inhibited $C$. albicans endocytosis, it stimulated the production of both IL-1 $\beta$ and IL-8. IFITM3 has been found to enhance the degradation of activated EGFR in pulmonary epithelial cells (38). Although knockdown of IFITM3 in oral epithelial cells had no detectable effect on total cellular EGFR levels or on EGFR phosphorylation, our results indicate that IFITM3 is a positive regulator of epithelial cell endocytosis of $C$. albicans but a negative regulator of cytokine production.

Our in-depth analysis of $\mathrm{gC} 1 \mathrm{qR}$ enabled us to develop a model for how this protein interacts with EGFR and is required for EGFR signaling in response to C. albicans infection (Fig. 8). We propose that gC1qR and EGFR form part of a complex that interacts either directly or indirectly with the C. albicans Als3 invasin. According to this model, $\mathrm{gC} 1 \mathrm{qR}$ is required for Als3 to maximally interact with and activate EGFR. In turn, EGFR is required for $C$. albicans to interact optimally with $\mathrm{gC1qR}$. This arrangement is deduced from the proteomics analysis, which showed that $\mathrm{gC1qR}$ was associated with EGFR, and from pulldown assays, which indicated that blocking gC1qR inhibited the physical association of EGFR with C. albicans and that blocking EGFR in turn reduced the association of $\mathrm{gC} 1 \mathrm{qR}$ with the organism. Although the proteomics analysis suggested that $\mathrm{gC1qR}$ associated with EGFR constitutively, the proximity ligation assay showed that the gC1qR-EGFR complex was enriched in regions surrounding C. albicans hyphae that expressed Als3. Previously, we found that Als3 is required for $C$. albicans to induce maximal EGFR activation (13). Accordingly, these results suggest that $\mathrm{gC} 1 \mathrm{qR}$ is a key cofactor that is required for Als3 to activate EGFR (Fig. 8). 
Although EGF also activates EGFR, we found that it does so independently of $\mathrm{gC1qR}$. These findings differ from those of Kim et al. (46), who reported that inhibition of $\mathrm{gC1qR}$ in the A549 lung cancer cell line blocked activation of EGFR induced by EGF. Possible reasons for these discrepant results include differences in the cell lines and the anti-gC1qR antibodies that we used compared to those used by the other investigators. We also found that blocking gC1qR did not prevent activation of EGFR by candidalysin. Collectively, these data suggest that soluble stimuli activate EGFR in oral epithelial cells independently of $\mathrm{gC} 1 \mathrm{qR}$, whereas $C$. albicans hyphae that express Als3 activate EGFR by a mechanism that requires $\mathrm{gC} 1 \mathrm{qR}$.

When investigating the role of $\mathrm{gC} 1 \mathrm{qR}$ in mediating the production of IL- $1 \beta$ and IL- 8 in response to $C$. albicans infection, we observed that treatment with the anti-gC1qR antibody inhibited the production of these inflammatory mediators, whereas siRNA knockdown of $\mathrm{gC} 1 \mathrm{qR}$ had the opposite effect. The likely explanation for these results is that inhibiting just extracellular $\mathrm{gC} 1 \mathrm{qR}$ has a different effect than decreasing the levels of intracellular gC1qR. Our experiments with the anti-gC1qR antibody indicate that it inhibits the production of proinflammatory mediators by blocking $C$. albicans-induced activation of EGFR and EphA2. These latter two receptors play key roles in stimulating the production of cytokines and chemokines in response to $C$. albicans $(15,16)$. Why reducing the levels of intracellular $\mathrm{gC} 1 \mathrm{qR}$ stimulates the production of proinflammatory mediators in oral epithelial cells is unknown. However, knockdown of $\mathrm{gC} 1 \mathrm{qR}$ in macrophages is known to reduce the cytoplasmic levels of tumor necrosis factor alpha-inducible protein 3 (TNFAIP3, A20), a suppressor of NF- $\kappa$ B activation, thereby stimulating the production of proinflammatory mediators (55). We speculate that $a$ similar process may occur when $\mathrm{gC1qR}$ is knocked down in oral epithelial cells.

Inhibition of EGFR in mice with oropharyngeal candidiasis reduces oral fungal burden and inflammation (16). Thus, we were surprised to determine that treating mice with the anti-gC1qR antibody failed to inhibit either of these parameters. Subsequently, we found that although this antibody inhibited C. albicans-induced phosphorylation of EGFR in primary human oral epithelial cells, it had no effect on primary mouse oral epithelial cells. The probable explanation for these results is that $\mathrm{gC1qR}$ is dispensable for the fungus to activate EGFR in mouse epithelial cells. Although it is also possible that the anti-gC1qR antibody used in the mouse studies did not block the association of gC1qR with EGFR in mouse cells, this seems unlikely because siRNA knockdown of EGFR in mouse oral epithelial cells also failed to inhibit EGFR phosphorylation in response to $C$. albicans.

We also found that although siRNA knockdown of IFITM3 inhibited the endocytosis of $C$. albicans by both the human OKF6/TERT-2 oral epithelial cell line and primary human oral epithelial cells, it had no significant effect on primary mouse oral epithelial cells. Collectively, these data suggest that two components of the EGFR signaling pathway, gC1qR and IFITM3, function differently in human versus mouse oral epithelial cells.

$\mathrm{gC1qR}$ is exploited by multiple microbial pathogens. gC1qR mediates the adherence of Plasmodium falciparum and Staphylococcus aureus to vascular endothelial cells and the adherence of Bacillus cereus spores to epithelial cells $(44,45,56,57)$. It is also an epithelial cell receptor for the $L$. monocytogenes internalin $B(\operatorname{InI} B)$ invasin and mediates the endocytosis of the organism (28). Because $\mathrm{gC1}$ qR lacks a transmembrane sequence, it is thought to induce endocytosis by signaling via another cell surface receptor. In the case of $L$. monocytogenes, the second receptor appears to be Met, the hepatocyte growth factor receptor (58). In some cell lines, gC1qR and Met have been found to function cooperatively to mediate the endocytosis of this bacterium (59). Although the primary amino acid sequence of the C. albicans Als3 invasin shares no homology with InIB, we have demonstrated that Als3 also interacts with gC1qR. Instead of Met, EGFR is the second receptor that associates with $\mathrm{gC1qR}$ and transduces the epithelial cell response C. albicans. Not only is $\mathrm{gC1qR}$ required for EGFR-mediated endocytosis of the fungus, but it is also necessary for the maximal epithelial cell inflammatory response to this organism. We have identified additional host cell receptors for $C$. albicans, including E-cadherin, HER2, the platelet-derived growth factor BB, the aryl hydrocarbon receptor, and gp96 (12-14, 18, 60). Whether gC1qR also interacts with these receptors remains to be determined. 


\section{MATERIALS AND METHODS}

Epithelial cells and fungal strains. The OKF6/TERT-2 oral epithelial cell line was provided by J. Rheinwald (Dana-Farber/Harvard Cancer Center, Boston, MA) and cultured as outlined previously (14, 17). Primary oral mucosal epithelial cells from humans and BALB/C mice were obtained from Cell Biologics, Inc., and grown following the manufacturer's instructions. NIH/3T3 cells that expressed human EGFR and HER2 were provided by Nadege Gaborit (Institut de Researche en Cancérologie de Montpellier, France) and grown as described previously (48). The C. albicans wild-type strain SC5314 and the als $1 \Delta / \Delta, a l s 3 \Delta / \Delta$, and ece $1 \Delta / \Delta$ mutants (16) were grown in yeast extract-peptone-dextrose (YPD) broth in a shaking incubator at $30^{\circ} \mathrm{C}$ for $18 \mathrm{~h}$, after which the cells were pelleted by centrifugation and washed twice with phosphate-buffered saline (PBS). Yeast cells were suspended in PBS, diluted, and counted with a hemacytometer.

Immunoprecipitation. OKF6/TERT-2 oral epithelial cells were grown to confluence in $75-\mathrm{cm}^{2}$ tissue culture flasks, and the culture medium was changed to KSF medium without supplements (Thermo Fisher Scientific; number 17005042) the night before the experiment. The next morning, cells were incubated for 90 min with supplement-free KSF medium containing $10^{8} \mathrm{C}$. albicans yeast cells or for $5 \mathrm{~min}$ with $50 \mathrm{ng} / \mathrm{ml}$ EGF. Cells incubated with fresh supplement-free KSF alone were processed in parallel as a negative control. After incubation, the medium was aspirated, and the cells were washed once with icecold PBS with $\mathrm{Ca}^{2+}$ and $\mathrm{Mg}^{2+}\left(\mathrm{PBS}^{++}\right)$. The proteins were cross-linked by incubation with $4 \%$ paraformaldehyde for $10 \mathrm{~min}$. After rinsing the cells twice with ice cold $\mathrm{PBS}^{++}$, they were detached from the culture flasks with a cell scraper and collected by centrifugation. The cell pellet was lysed with $5.8 \%$ octyl- $\beta$-Dglucopyranoside (VWR; number 97061-760) with sonication. The lysate was clarified by centrifugation and then precleared with protein A/G magnetic beads (Thermo Fisher Scientific; number PI88802) for $30 \mathrm{~min}$ at $4^{\circ} \mathrm{C}$. The precleared cell lysates were incubated with an anti-EGFR antibody (Santa Cruz Biotechnology; number SC-101, clone R-1) for $1 \mathrm{~h}$ at $4^{\circ} \mathrm{C}$ and precipitated with protein $\mathrm{A} / \mathrm{G}$ magnetic beads for $2 \mathrm{~h}$ at $4^{\circ} \mathrm{C}$. After the beads were washed 3 times with $1.5 \%$ octyl- $\beta$-D-glucopyranoside, the proteins were eluted with $8 \mathrm{M}$ urea and stored at $-80^{\circ} \mathrm{C}$.

Mass spectrometry. The protein samples were treated with Tris (2-carboxyethyl) phosphine hydrochloride (Thermo Fisher Scientific; number 20491) and 2-chloroacetamide (catalog number 154955) for reduction and alkylation, respectively. Tris buffer $(0.1 \mathrm{M}[\mathrm{pH} 8.5])$ was added to each sample to decrease the urea concentration to a final concentration of $2 \mathrm{M}$. After dilution, the samples were digested with lysyl endopeptidase (Fujifilm Wako Chemicals; number 125-05061) and trypsin (Thermo Fisher Scientific; number 90058 ) for $20 \mathrm{~h}$ at $37^{\circ} \mathrm{C}$. After quenching the reaction by adjusting the $\mathrm{pH}$ to 3 , the digested samples were desalted using $C_{18}$ columns (Thermo Fisher Scientific; number 89870 ) and then dried by vacuum centrifuge.

For the LC-MS/MS analysis, the samples were dissolved in $0.2 \%$ formic acid (FA) solution. The analysis was performed using an EASY-nLC 1000 (Thermo Fisher Scientific) connected to a Q Exactive Orbitrap mass spectrometers (Thermo Fisher Scientific). Solvent A consisted of $99.9 \% \mathrm{H}_{2} \mathrm{O}$ and $0.1 \% \mathrm{FA}$, and solvent $\mathrm{B}$ consisted of $19.9 \% \mathrm{H}_{2} \mathrm{O}, 80 \%$ acetonitrile, and $0.1 \%$ FA. Each sample was loaded onto an Easy Spray column ( $25 \mathrm{~cm}$ by $75 \mu \mathrm{m}, 2-\mu \mathrm{m} \mathrm{C}_{18}$, ES802; Thermo Fisher Scientific) and separated over $90 \mathrm{~min}$ at a flow rate of $0.5 \mu \mathrm{l} / \mathrm{min}$ with the following gradient: 2 to $35 \% \mathrm{~B}(75 \mathrm{~min}), 35$ to $85 \%$ B (5 min), and $85 \%$ $B(10 \mathrm{~min})$. The full MS scan was acquired at 70,000 resolution with a scan range of 350 to $2,000 \mathrm{~m} / \mathrm{z}$, an automatic gain control target of $1 \times 10^{6}$, and a maximum injection time of $100 \mathrm{~ms}$. The dd-MS2 scan was acquired at 17,500 resolution with a scan range of 200 to $2,000 \mathrm{~m} / \mathrm{z}$, an automatic gain control target of $5 \times 10^{4}$, a maximum injection time of $64 \mathrm{~ms}$, and an isolation window of $2.0 \mathrm{~m} / \mathrm{z}$. The proteomic data processing was performed using Proteome Discoverer 1.4 (Thermo Fisher Scientific) and the Sequest HT search engine. The search allowed for a precursor mass tolerance of $10 \mathrm{ppm}$, a minimum peptide length of 6 , and a minimum peptide sequence number of 1 .

Proximity ligation assay. To determine if the selected proteins associated with EGFR in intact epithelial cells, OKF6/TERT-2 cells were grown to confluence on fibronectin-coated coverslips. The cells were infected with $3 \times 10^{5} \mathrm{C}$. albicans yeast cells in supplement-free KSF medium. After $90 \mathrm{~min}$, the medium was aspirated, and the cells were fixed with $4 \%$ paraformaldehyde for $10 \mathrm{~min}$. The coverslips were washed 3 times with PBS, after which the epithelial cells were permeabilized with $0.1 \%$ Triton X-100 in PBS for 20 min. The association between EGFR and WBP2, GBP6, TOLLIP, EEA1, DSG3, IFITM3, or gC1qR was detected using the Duolink In Situ Red Starter kit Mouse/Rabbit (Sigma-Aldrich; number DUO921011 kit) according to the manufacturer's instruction. The antibodies used were rabbit anti-EGFR (Genetex; number GTX121919, clone N1-2), mouse anti-EGFR (Santa Cruz Biotechnology; number SC-101, clone R1), anti-WBP2 (Santa Cruz Biotechnology; number SC-514247, clone D-12), anti-GBP6 (Sigma-Aldrich; number HPA027744), anti-TOLLIP (Proteintech; number 117315-1), anti-EEA1 (Santa Cruz Biotechnology; number SC-365652 clone E-8), anti-DSG3 (Santa Cruz Biotechnology; number SC-53487, clone 5g11), anti-IFITM3 (Proteintech; number 11714-1), and gC1qR (Santa Cruz Biotechnology; number SC-23885, clone 74.5.2). The cells were imaged by confocal microscopy, and $z$ stacks of the images were constructed using the Leica Application Suite $\mathrm{X}$ software (Leica).

siRNA. To knock down the levels of selected proteins, the OKF6/TERT-2 cells were grown in 6-well tissue culture plates to 50 to $80 \%$ confluence overnight. The next morning, the cells were transfected with EGFR (Santa Cruz Biotechnology; number SC-29301), WBP2 (Santa Cruz Biotechnology; number SC93955), TOLLIP (Dharmacon; number L-016930-00-0005), IFITM3 (Santa Cruz Biotechnology; number SC-97053), gC1qR (Santa Cruz Biotechnology; number SC-42880), or control (Qiagen; number 1027281) siRNA using Lipofectamine RNAiMAX (Invitrogen; number 13778150) following the manufacturer's instructions. After $24 \mathrm{~h}$ posttransfection, the cells were seeded onto fibronectin-coated coverslips and incubated for another $24 \mathrm{~h}$ before use in the experiments. The extent of protein knockdown was 
determined by immunoblotting, and total loading was detected by probing the blots with an antiGAPDH (anti-glyceraldehyde-3-phosphate dehydrogenase) antibody (Cell Signaling; number 5174, clone D16H11).

Epithelial cell endocytosis and cell-association. Our standard differential fluorescence assay was used to measure the number of $C$. albicans cells that were endocytosed by and cell associated with the OKF6/TERT-2 epithelial cells, primary mouse and human oral epithelial cells, and NIH/3T3 cells (13, 18, 22). The host cells were infected with $10^{5} \mathrm{C}$. albicans yeast cells. To ensure similar levels of endocytosis among the different host cells, the incubation times were $2.5 \mathrm{~h}$ for OKF6/TERT-2 cells and primary human oral epithelial cells, $2 \mathrm{~h}$ for the mouse oral epithelial cells, and $1.5 \mathrm{~h}$ for the NIH/3T3 cells. In the siRNA experiments, the transfected epithelial cells were seeded onto fibronectin-coated glass coverslips $24 \mathrm{~h}$ before infection. For experiments using gefitinib (1 $\mu \mathrm{M}$; Selleck Chem, Inc.; number S1025) or the anti-gC1qR antibodies $(10 \mu \mathrm{g} / \mathrm{ml})$, the inhibitor or antibodies were added to the host cells $1 \mathrm{~h}$ prior to infection, and they remained in the medium for the duration of the experiment. All experiments performed in triplicate at least three times.

Lentivirus construction and production and host cell transduction. The transfer vectors (pLentiEF1A-EGFP-BLAST or pLenti-EF1A-hC1QBP[NM_001212.4]-BLAST) were constructed by cloning enhanced green fluorescent protein (eGFP) or hC1QBP[NM_001212.4] into pLenti-Cas9-BLAST (Addgene; number 52962) at the BamHI and Xbal sites. The virus was produced by transfecting HEK293T cells with plasmid psPAX2 (Addgene; number 12260), plasmid pCMV-VSVG (Addgene; number 8454), and transfer vector (pLenti-EF1A-EGFP-BLAST or pLenti-EF1A-hC1QBP[NM_001212.4]-BLAST) using the X-tremeGENE 9 DNA transfection reagent (Sigma-Aldrich; number 6365787001) according to the manufacturer's instructions. The supernatant containing the virus was collected at $60 \mathrm{~h}$ posttransfection, passed through a $0.45-\mu \mathrm{m}-$ pore polyvinylidene difluoride (PVDF) filter, and stored at $4{ }^{\circ} \mathrm{C}$ (short term) or $-80^{\circ} \mathrm{C}$ (long term).

For transduction, the NIH/3T3 mouse fibroblast cells (untransformed control cells or the human EGFR/hHER2-transformed cell line [48]) were seeded into a 6-well plate in Dulbecco's modified Eagle's medium (DMEM) plus 10\% bovine calf serum. The cells were transduced with lentivirus in the presence of $0.5 \mu \mathrm{g} / \mathrm{ml}$ Polybrene (Santa Cruz Biotechnology; number SC134220). The plates were centrifuged at $1,000 \times g$ for $30 \mathrm{~min}$ and then incubated at $37^{\circ} \mathrm{C}$ in $5 \% \mathrm{CO}_{2}$ overnight. The next morning, the cells were transferred to $10-\mathrm{cm}$-diameter tissue culture dishes. Two days postransduction, $10 \mu \mathrm{g} / \mathrm{ml}$ of blasticidin (Gibco; number A1113903) was added to the medium to select for transduced cells, and selection was maintained for 7 days. The successful transduction of eGFP was determined by fluorescence microscopy, and transduction of $\mathrm{hC1QBP}(\mathrm{gC} 1 \mathrm{qR})$ was verified via immunoblotting with an anti-gC1qR antibody (clone 74.5.2) and an anti-EGFR antibody (Cell Signaling Technology; number 4267, clone 38B1).

Receptor phosphorylation. Analysis of the phosphorylation of EGFR and EphA2 was performed as previously described $(11,16)$. Briefly, the oral epithelial cells were seeded onto 24-well tissue culture plates and incubated overnight in supplement-free KSF medium. The next morning, the cells were treated with gefitinib, an anti-gC1qR antibody (clone 74.5.2), or control mouse IgG (R\&D Systems; number MAB002) for $1 \mathrm{~h}$. The cells were then stimulated with $10^{6} \mathrm{C}$. albicans yeast cells for $90 \mathrm{~min}, 40 \mu \mathrm{M}$ candidalysin (Biomatik) for $5 \mathrm{~min}$, or $1 \mathrm{ng} / \mathrm{ml} \mathrm{EGF}$ for $5 \mathrm{~min}$ in the presence of the inhibitor or antibody. Next, the cells were lysed with $100 \mu \mathrm{l} 2 \times$ SDS loading buffer in the present of phosphatase inhibitor cocktail (Sigma-Aldrich), protease inhibitor cocktail (Sigma-Aldrich), and phenylmethylsulfonyl fluoride (PMSF) (Sigma-Aldrich). After the samples were denatured at $90^{\circ} \mathrm{C}$ for $2 \mathrm{~min}$, they were clarified by centrifugation. The proteins were separated by SDS-PAGE and transferred to PVDF membranes. Phosphorylated EGFR (Tyr 1068) was detected with a phospho-specific antibody (Cell Signaling Technology; number 2234) and enhanced chemiluminescence. Total EGFR was detected with an antiEGFR antibody (Cell Signaling Technology; number 4267). Phosphorylation of EphA2 (Ser 897) was detected with a phospho-specific anti-EphA2 antibody (Cell Signaling Technology; number 6347, clone D9A1), and total EphA2 was detected with an anti-EphA2 antibody (Cell Signaling Technology; number 6997, clone D4A2). The phosphorylation of EGFR in mouse oral epithelial cells was determined similarly, except that total EGFR was detected with anti-EGFR antibody from Santa Cruz Biotechnology (number SC373746, clone A-10). All experiments were repeated at least three times.

C. albicans association with epithelial cell gC1qR and EGFR. The capacity of anti-gC1qR and antiEGFR antibodies to block the association of $C$. albicans with $\mathrm{gC1qR}$ and EGFR was determined using our previously described method (61). Confluent OKF6/TERT-2 epithelial cells in a 6-well tissue culture plate were switched to supplement-free KSF medium the night before the experiment. The next morning, the epithelial cells were incubated with $10 \mu \mathrm{g} / \mathrm{ml}$ of control mouse IgG, an anti-gC1qR antibody (clone 74.5.2), or an anti-EGFR antibody (cetuximab; Lilly) for $1 \mathrm{~h}$, and then infected with $6 \times 10^{6} \mathrm{C}$. albicans blastospores. After 90 min of infection, the cells were detached with a cell scraper and collected by centrifugation. The epithelial cells were lysed by incubation with $5.8 \% n$-octyl- $\beta$-D-glucopyranoside in $\mathrm{PBS}^{++}$in the present of protease inhibitors and PMSF on ice for $1 \mathrm{~h}$. The samples were centrifuged at $5,000 \times g$ for $1 \mathrm{~min}$, and the supernatants containing the total cell lysates were collected. The pellets, which contained the intact $C$. albicans cells and the epithelial cell proteins that were associated with them, were washed three times with cold $1.5 \% n$-octyl- $\beta$-D-glucopyranoside in $\mathrm{PBS}^{++}$containing protease inhibitors. The proteins that remained associated with the $C$. albicans cells were eluted by incubation with $6 \mathrm{M}$ urea for $30 \mathrm{~min}$ on ice. After pelleting the organisms by centrifugation, the eluted proteins in the supernatants were separated by SDS-PAGE. The presence of $\mathrm{gC} 1 \mathrm{qR}$ and EGFR in the eluates was determined by immunoblotting with an anti-gC1qR antibody (Abcam; number ab24733, clone 60.11) and an anti-EGFR antibody (clone 38B1). The experiment was repeated four times.

Cytokine and chemokine measurement. To measure the production of IL- $1 \beta$ and IL- 8 by oral epithelial cells, the OKF6/TERT-2 cells were grown in 48-well tissue culture plates overnight in supplement- 
free KSF and then infected with $6.25 \times 10^{5} \mathrm{C}$. albicans yeast cells for $8 \mathrm{~h}$. The conditioned medium was collected and clarified by centrifugation. The levels of IL-1 $\beta$ and IL-8 in the conditioned medium were measured by ELISA using the human IL-1 $\beta$ DuoSet (R\&D Systems; number DY20105) and the human IL8 set (BD Biosciences; number BD555244).

The production of IL- $1 \beta, \mathrm{IL}-8, \mathrm{IL}-1 \alpha$, and GM-CSF by the epithelial cells was measured similarly, except that the epithelial cells were grown in 24-well tissue culture plates and infected with $1.5 \times 10^{6} \mathrm{C}$. albicans yeast cells. The levels of the inflammatory mediators were measured by Luminex Multiplex (R\&D Systems; number LXSAHM-06). The experiments were repeated three times in duplicate.

Mouse experiments. Our standard immunocompetent mouse model of oropharyngeal candidiasis was used to assess the effects of an anti-gC1qR antibody and gefitinib on the infection $(11,16,62)$. Immunocompetent BALB/c mice were administered $100 \mu \mathrm{g}$ of the anti-gC1qR antibody (clone 74.5.2) by intraperitoneal injection on day -1 relative to infection. Control mice were injected with a similar amount of mouse $\mathrm{lgG}$. Gefitinib was administered by adding the drug to powdered chow to a final concentration of $200 \mathrm{ppm}$, starting at day -2 relative to infection and continuing throughout the experiment. On the day of the infection, the mice were sedated, and a calcium alginate swab saturated with $2 \times 10^{7} \mathrm{C}$. albicans yeast cells was placed sublingually for $75 \mathrm{~min}$. After 1 day of infection, the mice were sacrificed, and the tongues were excised, weighed, and homogenized. The oral fungal burden was determined by quantitative culture of an aliquot of the homogenates, and the level of MPO in the homogenates was determined by commercial ELISA (Hycult Biotech; number HK210-02). The experiment was repeated twice using 4 to 5 mice per condition, and the results were combined.

Statistical analysis. The in vitro data were analyzed using one-way analysis of variance with Dunnett's test for multiple comparisons. The mouse data were analyzed by the Kruskal-Wallis test with Dunn's test for multiple comparisons. $P$ values of $\leq 0.05$ were considered to be significant.

\section{SUPPLEMENTAL MATERIAL}

Supplemental material is available online only.

FIG S1, PDF file, $0.2 \mathrm{MB}$.

FIG S2, PDF file, $0.3 \mathrm{MB}$.

FIG S3, PDF file, $0.02 \mathrm{MB}$.

FIG S4, PDF file, $0.3 \mathrm{MB}$.

FIG S5, PDF file, $0.4 \mathrm{MB}$.

TABLE S1, XLSX file, 0.1 MB.

TABLE S2, XLSX file, 0.1 MB.

TABLE S3, XLSX file, $0.01 \mathrm{MB}$.

\section{ACKNOWLEDGMENTS}

We thank Adam Diab for assistance with tissue culture.

The work was supported in part by NIH grants R01DE026600 and R01Al124566 to S.G.F., R00DE026856 to M.S., and DE022550 to S.L.G.

\section{REFERENCES}

1. Hauman $\mathrm{CH}$, Thompson IO, Theunissen F, Wolfaardt P. 1993. Oral carriage of Candida in healthy and HIV-seropositive persons. Oral Surg Oral Med Oral Pathol 76:570-572. https://doi.org/10.1016/0030-4220(93)90064-b.

2. Verma A, Gaffen SL, Swidergall M. 2017. Innate immunity to mucosal Candida infections. J Fungi 3:60. https://doi.org/10.3390/jof3040060.

3. Berberi A, Noujeim Z, Aoun G. 2015. Epidemiology of oropharyngeal candidiasis in human immunodeficiency virus/acquired immune deficiency syndrome patients and CD4+ counts. J Int Oral Health 7:20-23.

4. Gligorov J, Bastit L, Gervais H, Henni M, Kahila W, Lepille D, Luporsi E, Sasso G, Varette C, Azria D, Candidoscope Study Group. 2011. Prevalence and treatment management of oropharyngeal candidiasis in cancer patients: results of the French CANDIDOSCOPE study. Int J Radiat Oncol Biol Phys 80:532-539. https://doi.org/10.1016/j.ijrobp.2010.02.006.

5. Sanitá PV, Pavarina AC, Giampaolo ET, Silva MM, Mima EG, Ribeiro DG, Vergani CE. 2011. Candida spp. prevalence in well controlled type 2 diabetic patients with denture stomatitis. Oral Surg Oral Med Oral Pathol Oral Radiol Endod 111:726-733. https://doi.org/10.1016/j.tripleo.2011.02.033.

6. Schwartz IS, Patterson TF. 2018. The emerging threat of antifungal resistance in transplant infectious diseases. Curr Infect Dis Rep 20:2. https://doi .org/10.1007/s11908-018-0608-y.

7. Patel PK, Erlandsen JE, Kirkpatrick WR, Berg DK, Westbrook SD, Louden C, Cornell JE, Thompson GR, Vallor AC, Wickes BL, Wiederhold NP, Redding SW, Patterson TF. 2012. The changing epidemiology of oropharyngeal candidiasis in patients with HIV/AIDS in the era of antiretroviral therapy. AIDS Res Treat 2012:262471. https://doi.org/10.1155/2012/262471.

8. Dotta L, Scomodon O, Padoan R, Timpano S, Plebani A, Soresina A, Lougaris V, Concolino D, Nicoletti A, Giardino G, Licari A, Marseglia G, Pignata C, Tamassia N, Facchetti F, Vairo D, Badolato R. 2016. Clinical heterogeneity of dominant chronic mucocutaneous candidiasis disease: presenting as treatment-resistant candidiasis and chronic lung disease. Clin Immunol 164:1-9. https://doi.org/10.1016/j.clim.2015.12.010.

9. Aggor FEY, Break TJ, Trevejo-Nuñez G, Whibley N, Coleman BM, Bailey RD, Kaplan DH, Naglik JR, Shan W, Shetty AC, McCracken C, Durum SK, Biswas PS, Bruno VM, Kolls JK, Lionakis MS, Gaffen SL. 2020. Oral epithelial IL-22/ STAT3 signaling licenses IL-17-mediated immunity to oral mucosal candidiasis. Sci Immunol 5:eaba0570. https://doi.org/10.1126/sciimmunol.aba0570.

10. Conti HR, Bruno VM, Childs EE, Daugherty S, Hunter JP, Mengesha BG, Saevig DL, Hendricks MR, Coleman BM, Brane L, Solis N, Cruz JA, Verma AH, Garg AV, Hise AG, Richardson JP, Naglik JR, Filler SG, Kolls JK, Sinha S, Gaffen SL. 2016. IL-17 receptor signaling in oral epithelial cells is critical for protection against oropharyngeal candidiasis. Cell Host Microbe 20: 606-617. https://doi.org/10.1016/j.chom.2016.10.001.

11. Swidergall M, Solis NV, Lionakis MS, Filler SG. 2018. EphA2 is an epithelial cell pattern recognition receptor for fungal $\beta$-glucans. Nat Microbiol 3: 53-61. https://doi.org/10.1038/s41564-017-0059-5.

12. Liu Y, Shetty AC, Schwartz JA, Bradford LL, Xu W, Phan QT, Kumari $P$, Mahurkar A, Mitchell AP, Ravel J, Fraser CM, Filler SG, Bruno VM. 2015. 
New signaling pathways govern the host response to $C$. albicans infection in various niches. Genome Res 25:679-689. https://doi.org/10.1101/gr.187427.114.

13. Zhu W, Phan QT, Boontheung P, Solis NV, Loo JA, Filler SG. 2012. EGFR and HER2 receptor kinase signaling mediate epithelial cell invasion by Candida albicans during oropharyngeal infection. Proc Natl Acad Sci U S A 109:14194-14199. https://doi.org/10.1073/pnas.1117676109.

14. Solis NV, Swidergall M, Bruno VM, Gaffen SL, Filler SG. 2017. The aryl hydrocarbon receptor governs epithelial cell invasion during oropharyngeal candidiasis. mBio 8:e00025-17. https://doi.org/10.1128/mBio.00025-17.

15. Ho J, Yang X, Nikou SA, Kichik N, Donkin A, Ponde NO, Richardson JP, Gratacap RL, Archambault LS, Zwirner CP, Murciano C, Henley-Smith R, Thavaraj S, Tynan CJ, Gaffen SL, Hube B, Wheeler RT, Moyes DL, Naglik JR. 2019. Candidalysin activates innate epithelial immune responses via epidermal growth factor receptor. Nat Commun 10:2297. https://doi.org/10 .1038/s41467-019-09915-2.

16. Swidergall M, Solis NV, Millet N, Huang MY, Lin J, Phan QT, Lazarus MD, Wang Z, Yeaman MR, Mitchell AP, Filler SG. 2021. Activation of EphA2-EGFR signaling in oral epithelial cells by Candida albicans virulence factors. PLoS Pathog 17:e1009221. https://doi.org/10.1371/journal.ppat.1009221.

17. Dickson MA, Hahn WC, Ino Y, Ronfard V, Wu JY, Weinberg RA, Louis DN, Li FP, Rheinwald JG. 2000. Human keratinocytes that express hTERT and also bypass a p16(INK4a)-enforced mechanism that limits life span become immortal yet retain normal growth and differentiation characteristics. Mol Cell Biol 20: 1436-1447. https://doi.org/10.1128/MCB.20.4.1436-1447.2000.

18. Phan QT, Myers CL, Fu Y, Sheppard DC, Yeaman MR, Welch WH, Ibrahim AS, Edwards JE, Filler SG. 2007. Als3 is a Candida albicans invasin that binds to cadherins and induces endocytosis by host cells. PLoS Biol 5:e64. https://doi.org/10.1371/journal.pbio.0050064.

19. El-Sayed A, Harashima H. 2013. Endocytosis of gene delivery vectors: from clathrin-dependent to lipid raft-mediated endocytosis. Mol Ther 21: 1118-1130. https://doi.org/10.1038/mt.2013.54.

20. Otto GP, Nichols BJ. 2011. The roles of flotillin microdomains-endocytosis and beyond. J Cell Sci 124:3933-3940. https://doi.org/10.1242/jcs.092015.

21. Moreno-Ruiz E, Galan-Diez M, Zhu W, Fernandez-Ruiz E, d'Enfert C, Filler SG, Cossart P, Veiga E. 2009. Candida albicans internalization by host cells is mediated by a clathrin-dependent mechanism. Cell Microbiol 11: 1179-1189. https://doi.org/10.1111/j.1462-5822.2009.01319.x.

22. Park H, Myers CL, Sheppard DC, Phan QT, Sanchez AA, Edwards JE, Jr, Filler SG. 2005. Role of the fungal Ras-protein kinase A pathway in governing epithelial cell interactions during oropharyngeal candidiasis. Cell Microbiol 7:499-510. https://doi.org/10.1111/j.1462-5822.2004.00476.x.

23. Moreau V, Galan JM, Devilliers G, Haguenauer-Tsapis R, Winsor B. 1997. The yeast actin-related protein Arp2p is required for the internalization step of endocytosis. Mol Biol Cell 8:1361-1375. https://doi.org/10.1091/mbc.8.7.1361.

24. Engqvist-Goldstein AE, Zhang CX, Carreno S, Barroso C, Heuser JE, Drubin DG. 2004. RNAi-mediated Hip1R silencing results in stable association between the endocytic machinery and the actin assembly machinery. Mol Biol Cell 15:1666-1679. https://doi.org/10.1091/mbc.e03-09-0639.

25. Phillips DR, Jennings LK, Edwards HH. 1980. Identification of membrane proteins mediating the interaction of human platelets. J Cell Biol 86: 77-86. https://doi.org/10.1083/jcb.86.1.77.

26. Schaks M, Giannone G, Rottner K. 2019. Actin dynamics in cell migration. Essays Biochem 63:483-495. https://doi.org/10.1042/EBC20190015.

27. Itoh RE, Kiyokawa E, Aoki K, Nishioka T, Akiyama T, Matsuda M. 2008. Phosphorylation and activation of the Rac1 and Cdc42 GEF Asef in A431 cells stimulated by EGF. J Cell Sci 121:2635-2642. https://doi.org/10.1242/jcs.028647.

28. Braun L, Ghebrehiwet B, Cossart P. 2000. gC1q-R/p32, a C1q-binding protein, is a receptor for the InIB invasion protein of Listeria monocytogenes. EMBO J 19:1458-1466. https://doi.org/10.1093/emboj/19.7.1458.

29. Mengaud J, Ohayon H, Gounon P, Mege RM, Cossart P. 1996. E-cadherin is the receptor for internalin, a surface protein required for entry of $L$. monocytogenes into epithelial cells. Cell 84:923-932. https://doi.org/10 .1016/S0092-8674(00)81070-3.

30. Veiga E, Cossart P. 2005. Listeria hijacks the clathrin-dependent endocytic machinery to invade mammalian cells. Nat Cell Biol 7:894-900. https://doi .org/10.1038/ncb1292.

31. Zatloukal B, Kufferath I, Thueringer A, Landegren U, Zatloukal K, Haybaeck J. 2014. Sensitivity and specificity of in situ proximity ligation for protein interaction analysis in a model of steatohepatitis with Mallory-Denk bodies. PLoS One 9:e96690. https://doi.org/10.1371/journal.pone.0096690.

32. Li Z, Lim SK, Liang X, Lim YP. 2018. The transcriptional coactivator WBP2 primes triple-negative breast cancer cells for responses to Wnt signaling via the JNK/Jun kinase pathway. J Biol Chem 293:20014-20028. https:// doi.org/10.1074/jbc.RA118.005796.
33. Moyes DL, Shen C, Murciano C, Runglall M, Richardson JP, Arno M, Aldecoa-Otalora E, Naglik JR. 2014. Protection against epithelial damage during Candida albicans infection is mediated by PI3K/Akt and mammalian target of rapamycin signaling. J Infect Dis 209:1816-1826. https://doi .org/10.1093/infdis/jit824.

34. Moyes DL, Runglall M, Murciano C, Shen C, Nayar D, Thavaraj S, Kohli A, Islam A, Mora-Montes H, Challacombe SJ, Naglik JR. 2010. A biphasic innate immune MAPK response discriminates between the yeast and hyphal forms of Candida albicans in epithelial cells. Cell Host Microbe 8: 225-235. https://doi.org/10.1016/j.chom.2010.08.002.

35. Zhang Y, Lee C, Geng S, Li L. 2019. Enhanced tumor immune surveillance through neutrophil reprogramming due to Tollip deficiency. JCI Insight 4: e122939. https://doi.org/10.1172/jci.insight.122939.

36. Shah JA, Vary JC, Chau TT, Bang ND, Yen NT, Farrar JJ, Dunstan SJ, Hawn TR. 2012. Human TOLLIP regulates TLR2 and TLR4 signaling and its polymorphisms are associated with susceptibility to tuberculosis. J Immunol 189:1737-1746. https://doi.org/10.4049/jimmunol.1103541.

37. Didierlaurent A, Brissoni B, Velin D, Aebi N, Tardivel A, Käslin E, Sirard JC, Angelov G, Tschopp J, Burns K. 2006. Tollip regulates proinflammatory responses to interleukin-1 and lipopolysaccharide. Mol Cell Biol 26: 735-742. https://doi.org/10.1128/MCB.26.3.735-742.2006.

38. Spence JS, He R, Hoffmann HH, Das T, Thinon E, Rice CM, Peng T, Chandran K, Hang HC. 2019. IFITM3 directly engages and shuttles incoming virus particles to lysosomes. Nat Chem Biol 15:259-268. https://doi .org/10.1038/s41589-018-0213-2.

39. Jiang J, Zhang Y, Krainer AR, Xu RM. 1999. Crystal structure of human p32, a doughnut-shaped acidic mitochondrial matrix protein. Proc Natl Acad Sci U S A 96:3572-3577. https://doi.org/10.1073/pnas.96.7.3572.

40. Joseph K, Shibayama Y, Nakazawa Y, Peerschke El, Ghebrehiwet B, Kaplan AP. 1999. Interaction of factor XII and high molecular weight kininogen with cytokeratin 1 and $\mathrm{gC1qR}$ of vascular endothelial cells and with aggregated Abeta protein of Alzheimer's disease. Immunopharmacology 43:203-210. https://doi.org/10.1016/S0162-3109(99)00136-8.

41. Lim BL, Reid KB, Ghebrehiwet B, Peerschke El, Leigh LA, Preissner KT. 1996. The binding protein for globular heads of complement C1q, gC1qR. Functional expression and characterization as a novel vitronectin binding factor. J Biol Chem 271:26739-26744. https://doi.org/10.1074/jbc.271.43.26739.

42. Eggleton P, Ghebrehiwet B, Sastry KN, Coburn JP, Zaner KS, Reid KB, Tauber Al. 1995. Identification of a gC1q-binding protein ( $\mathrm{gC1q}-\mathrm{R})$ on the surface of human neutrophils. Subcellular localization and binding properties in comparison with the cC1q-R. J Clin Invest 95:1569-1578. https:// doi.org/10.1172/JCI117830.

43. Ghebrehiwet B, Lim BL, Peerschke El, Willis AC, Reid KB. 1994. Isolation, CDNA cloning, and overexpression of a $33-\mathrm{kD}$ cell surface glycoprotein that binds to the globular "heads" of C1q. J Exp Med 179:1809-1821. https://doi.org/10.1084/jem.179.6.1809.

44. Peerschke El, Bayer AS, Ghebrehiwet B, Xiong YQ. 2006. gC1qR/p33 blockade reduces Staphylococcus aureus colonization of target tissues in an animal model of infective endocarditis. Infect Immun 74:4418-4423. https://doi.org/10.1128/IAI.01794-05.

45. Biswas AK, Hafiz A, Banerjee B, Kim KS, Datta K, Chitnis CE. 2007. Plasmodium falciparum uses $\mathrm{gC} 1 \mathrm{qR} / \mathrm{HABP} 1 / \mathrm{p} 32$ as a receptor to bind to vascular endothelium and for platelet-mediated clumping. PLoS Pathog 3: 1271-1280. https://doi.org/10.1371/journal.ppat.0030130.

46. Kim BC, Hwang HJ, An HT, Lee H, Park JS, Hong J, Ko J, Kim C, Lee JS, Ko YG. 2016. Antibody neutralization of cell-surface gC1qR/HABP1/SF2-p32 prevents lamellipodia formation and tumorigenesis. Oncotarget 7: 49972-49985. https://doi.org/10.18632/oncotarget.10267.

47. Ghebrehiwet B, Lu PD, Zhang W, Lim BL, Eggleton P, Leigh LE, Reid KB, Peerschke El. 1996. Identification of functional domains on $\mathrm{gC1Q}-\mathrm{R}$, a cell surface protein that binds to the globular "heads" of C1Q, using monoclonal antibodies and synthetic peptides. Hybridoma 15:333-342. https:// doi.org/10.1089/hyb.1996.15.333.

48. Gaborit N, Larbouret C, Vallaghe J, Peyrusson F, Bascoul-Mollevi C, Crapez E, Azria D, Chardes T, Poul MA, Mathis G, Bazin H, Pelegrin A. 2011. Timeresolved fluorescence resonance energy transfer (TR-FRET) to analyze the disruption of EGFR/HER2 dimers: a new method to evaluate the efficiency of targeted therapy using monoclonal antibodies. J Biol Chem 286: 11337-11345. https://doi.org/10.1074/jbc.M111.223503.

49. Moyes DL, Wilson D, Richardson JP, Mogavero S, Tang SX, Wernecke J, Hofs S, Gratacap RL, Robbins J, Runglall M, Murciano C, Blagojevic M, Thavaraj S, Forster TM, Hebecker B, Kasper L, Vizcay G, lancu SI, Kichik N, Hader A, Kurzai O, Luo T, Kruger T, Kniemeyer O, Cota E, Bader O, Wheeler RT, Gutsmann T, Hube B, Naglik JR. 2016. Candidalysin is a fungal peptide 
toxin critical for mucosal infection. Nature 532:64-68. https://doi.org/10 1038/nature17625.

50. Riise GC, Andersson BA, Kjellstrom C, Martensson G, Nilsson FN, Ryd W Schersten H. 1999. Persistent high BAL fluid granulocyte activation marker levels as early indicators of bronchiolitis obliterans after lung transplant. Eur Respir J 14:1123-1130. https://doi.org/10.1183/09031936.99.14511239.

51. Schultz J, Kaminker K. 1962. Myeloperoxidase of the leucocyte of normal human blood. I. Content and localization. Arch Biochem Biophys 96: 465-467. https://doi.org/10.1016/0003-9861(62)90321-1.

52. Gouin E, Gantelet H, Egile C, Lasa I, Ohayon H, Villiers V, Gounon P, Sansonetti PJ, Cossart P. 1999. A comparative study of the actin-based motilities of the pathogenic bacteria Listeria monocytogenes, Shigella flexneri and Rickettsia conorii. J Cell Sci 112:1697-1708. https://doi.org/10 $.1242 / \mathrm{jcs} .112 .11 .1697$.

53. Skoble J, Auerbuch V, Goley ED, Welch MD, Portnoy DA. 2001. Pivotal role of VASP in Arp2/3 complex-mediated actin nucleation, actin branch-formation, and Listeria monocytogenes motility. J Cell Biol 155:89-100. https://doi.org/10.1083/jcb.200106061.

54. Rodnick-Smith M, Luan Q, Liu SL, Nolen BJ. 2016. Role and structural mechanism of WASP-triggered conformational changes in branched actin filament nucleation by Arp2/3 complex. Proc Natl Acad Sci U S A 113: E3834-E3843. https://doi.org/10.1073/pnas.1517798113.

55. Song X, Yao Z, Yang J, Zhang Z, Deng Y, Li M, Ma C, Yang L, Gao X, Li W Liu J, Wei L. 2016. HCV core protein binds to gC1qR to induce A20 expression and inhibit cytokine production through MAPKs and NF- $\kappa$ B signaling pathways. Oncotarget 7:33796-33808. https://doi.org/10.18632/oncotarget.9304.

56. Sethi S, Herrmann M, Roller J, von Müller L, Peerschke El, Ghebrehiwet $B$ Bajric I, Menger MD, Laschke MW. 2011. Blockade of gC1qR/p33, a receptor for C1q, inhibits adherence of Staphylococcus aureus to the microvascular endothelium. Microvasc Res 82:66-72. https://doi.org/10.1016/j.mvr.2011.04.007.

57. Peerschke El, Ghebrehiwet B. 2007. The contribution of $\mathrm{gC1qR/p33}$ in infection and inflammation. Immunobiology 212:333-342. https://doi .org/10.1016/j.imbio.2006.11.011.

58. Shen Y, Naujokas M, Park M, Ireton K. 2000. InIB-dependent internalization of Listeria is mediated by the Met receptor tyrosine kinase. Cell 103: 501-510. https://doi.org/10.1016/s0092-8674(00)00141-0.

59. Khelef N, Lecuit M, Bierne H, Cossart P. 2006. Species specificity of the Listeria monocytogenes InIB protein. Cell Microbiol 8:457-470. https://doi .org/10.1111/j.1462-5822.2005.00634.x.

60. Liu Y, Mittal R, Solis NV, Prasadarao NV, Filler SG. 2011. Mechanisms of Candida albicans trafficking to the brain. PLoS Pathog 7:e1002305. https://doi.org/10.1371/journal.ppat.1002305.

61. Phan QT, Eng DK, Mostowy S, Park H, Cossart P, Filler SG. 2013. Role of endothelial cell septin 7 in the endocytosis of Candida albicans. mBio 4: e00542-13. https://doi.org/10.1128/mBio.00542-13.

62. Solis NV, Filler SG. 2012. Mouse model of oropharyngeal candidiasis. Nat Protoc 7:637-642. https://doi.org/10.1038/nprot.2012.011. 